\title{
Pseudomonas syringae pv. tomato OxyR Is Required for Virulence in Tomato and Arabidopsis
}

\author{
Yasuhiro Ishiga $^{1}$ and Yuki Ichinose ${ }^{2}$ \\ ${ }^{1}$ Faculty of Life and Environmental Sciences, University of Tsukuba, 1-1-1 Tennodai, Tsukuba, Ibaraki 305-8572, Japan; \\ ${ }^{2}$ Laboratory of Plant Pathology and Genetic Engineering, Graduate School of Environmental and Life Science, Okayama \\ University, 1-1-1 Tsushima-naka, Okayama 700-8530, Japan
}

Submitted 8 September 2015. Accepted 7 November 2015.

\begin{abstract}
Reactive oxygen species (ROS) have been shown to have a crucial role in plant defense responses and signaling pathways. In addition, ROS also have direct toxicity against pathogens. However, the molecular mechanisms of plant ROS in the direct effects against pathogens is still unclear. To investigate the function of plant ROS in the interactions of plant and bacterial pathogens, we focused on oxyR, encoding an oxidative stressregulated transcription factor in Pseudomonas syringae pv. tomato DC3000 (DC3000), and generated an $\Delta$ oxyR mutant. The DC3000 $\Delta$ oxyR mutant showed high sensitivity to oxidative stress in comparison with wild type and the complemented line. The host plants of DC3000, including tomato and Arabidopsis inoculated with the $\Delta$ oxy $R$ mutant, clearly showed reduced disease symptoms as well as reduced bacterial populations. Expression profiles of DC3000 genes revealed that OxyR could regulate the expression of genes encoding ROS-detoxifying enzymes, including catalases (KatB and KatG), in response to ROS. We also demonstrated that the expression of katB could be regulated by OxyR during the infection of DC3000 in Arabidopsis. These results suggest that OxyR has an important role in the virulence of $\mathrm{DC} 3000$ by regulating the expression of genes related to oxidative stress.
\end{abstract}

Pseudomonas syringae induces a variety of symptoms such as leaf spots, cankers, and blights on different plants and can be classified into more than 50 pathovars (pv.), based on their host plant specificities and type of disease symptoms. $P$. syringae pv. tomato DC3000 (DC3000), which causes bacterial speck disease of tomato, has been used as a model pathogen to investigate the molecular basis of plant-pathogen interactions because of its genetic tractability and its pathogenicity on Arabidopsis (Abramovitch and Martin 2004; Ishiga et al. 2011; Katagiri et al. 2002). The whole genome sequence of DC3000 is predicted to have over 200 virulence-related genes (Buell et al. 2003). One of the major classes of virulence factors in DC3000 includes effector proteins that are delivered into the host through a type III protein secretion system (T3SS) to suppress host defense responses and, also, to facilitate disease development (Lindeberg et al. 2012; Nomura et al. 2005). In addition, DC3000 produces nonproteinaceous virulence

Corrresponding author: Y. Ishiga;

E-mail: ishiga.yasuhiro.km@u.tsukuba.ac.jp; Telephone and Fax: (+81) 029-853-4792.

*The $\boldsymbol{e}$-Xtra logo stands for "electronic extra" and indicates that three supplementary figures and one supplementary table are published online.

@ 2016 The American Phytopathological Society effectors, including coronatine (COR), which are critical for pathogenesis in tomato and Arabidopsis (Brooks et al. 2005; Uppalapati et al. 2007). Although there is a good understanding of the importance of T3SS effectors in the pathogenicity of DC3000, the virulence function of a large number of potential virulence effectors encoded in the DC3000 genome and their modes of action are not fully understood.

In all natural habitats, plants are constantly surrounded by an enormous number of microorganisms, including potential pathogens. Therefore, they have developed surveillance systems that recognize invading pathogens and orchestrate an array of immune responses to defend themselves against pathogens. The plant defense system consists of two main lines. The first line of defense is pathogen-associated molecular pattern (PAMP)triggered immunity (PTI) to recognize the conserved molecules from invading pathogens (microbes) using plant patternrecognition receptors (Zipfel 2008). The second line of defense that exists to defend plants from pathogens is effector-triggered immunity (ETI), based on the gene-for-gene interactions that are governed by individual plant resistance genes and their corresponding avirulence genes (Cui et al. 2015). PTI and ETI are known to induce similar sets of plant defense responses, including oxidative burst, callose ( $\beta$-1,3-glucan) deposition in the cell wall, and the induction of hormone-mediated signaling pathways leading to the expression of defense-related genes (Zhang and Zhou 2010; Zipfel 2008).

The oxidative burst, a rapid and transient production of reactive oxygen species (ROS), including superoxide $\left(\mathrm{O}_{2}^{-}\right)$and hydrogen peroxide $\left(\mathrm{H}_{2} \mathrm{O}_{2}\right)$, is one of the earliest defense responses during PTI and ETI. Doke (1983) first reported the generation of $\mathrm{O}_{2}^{-}$from the host cell membrane in incompatible interactions and demonstrated that the hyphal wall component elicitor (PAMP) from Phytophthora infestans activated ROS production leading to defense responses. To date, numerous studies have demonstrated that ROS have a key role in plant defense mechanisms and signaling pathways underlying PTI, ETI, and systemic acquired resistance (Grant and Lamb 2006; Zhang and Zhou 2010; Zipfel 2008). The apoplastic ROS are generated from plasma membrane-localized NADPH oxidases and cell wall-bound peroxidases. In addition to apoplastic ROS, chloroplastic ROS are also known to have an important role in plant defense mechanisms (Chandra-Shekara et al. 2006; Greenberg and Yao 2004; Loake 2001; Van Breusegem and Dat 2006). It is known that apoplastic ROS have multiple roles in plant defense mechanisms, including signaling molecules, formation of oxidative cross-linkages in the cell-wall lignification for a physical barrier, or direct toxicity against invading pathogens (Torres 2010). A recent study with a rbohD mutant in Arabidopsis demonstrated that the RbohD-mediated ROS burst 
has an important role in antibacterial immunity (Kadota et al. 2014). Therefore, bacterial pathogens must maintain the ability to detoxify apoplastic ROS to overcome plant ROS-mediated defense responses, including PTI. One of the important enzymes to detoxify apoplastic ROS is catalase. DC3000 has been shown to utilize catalase to detoxify $\mathrm{H}_{2} \mathrm{O}_{2}$ in Arabidopsis (Guo et al. 2012). Moreover, catalase mutants of DC3000 including $k a t B$ and $k a t G$ showed reduced virulence, indicating that catalase is required for the virulence of DC30000 (Guo et al. 2012). To modulate the expression of ROS-detoxifying enzymes including catalases, bacteria have evolved oxidative stress-inducible transcriptional regulators. Two of these transcriptional regulators, SoxR and OxyR, have been demonstrated to have a critical role in oxidative stress responses in numerous bacteria, including phytopathological bacteria such as Pantoea stewartii subsp. stewartii, Xylella fastidiosa, and Ralstonia solanacearum (Burbank and Roper 2014; FloresCruz and Allen 2011; Toledo et al. 2011). The whole-genome sequence studies of $P$. syringae revealed that OxyR is highly conserved among DC3000, P. syringae pv. syringae B728a, and P. syringae pv. phaseolicola 1448A (Buell et al. 2003; Feil et al. 2005; Joardar et al. 2005), however, there are no open reading frames (ORFs) encoding putative protein homologs to SoxR. OxyR is a DNA-binding transcriptional regulator that is activated in response to oxidative stress, especially $\mathrm{H}_{2} \mathrm{O}_{2}$, through the reversible disulfide bond formation of two cysteine residues (Pomposiello and Demple 2002; Zheng et al. 1998). OxyR has been shown to contribute to the virulence of bacterial pathogens, not only in animals but also in plants, including pathogens such as Pseudomonas aeruginosa, Escherichia coli, Pantoea stewartii subsp. stewartii, Ralstonia solanacearum, Xanthomonas campestris pv. campestris, and Erwinia chrysanthemi (Burbank and Roper 2014; Charoenlap et al. 2011; Flores-Cruz and Allen 2011; Johnson et al. 2013; Lau et al. 2005; Miguel et al. 2000).

In this study, we demonstrated that the DC3000 oxidative stress-inducible transcriptional regulator OxyR regulates the expression of genes related to ROS-detoxifying enzymes including catalases, under oxidative stress conditions. Furthermore, the DC3000 $\triangle$ oxyR mutant showed reduced virulence during host plant infection, indicating that OxyR is required for full virulence. Thus, our results suggest the importance of ROSdetoxifying mechanisms including the OxyR transcriptional regulator and enzymes in the virulence of DC3000.

\section{RESULTS}

OxyR is required for protection of $P$. syringae pv. tomato DC3000 from exogenous and endogenous ROS toxicity.

The $\operatorname{oxy} R$ gene was identified in the DC3000 genome (Buell et al. 2003) and is conserved in other $P$. syringae strains, including pvs. syringae B728A (Feil et al. 2005) and phaseolicola 1448A (Joardar et al. 2005), with almost identical amino acid sequences (Supplementary Fig. S1). The OxyR of $P$. syringae has high similarity with that of $P$. aeruginosa PAO1, suggesting that OxyR has a conserved fundamental function among Pseudomonas species.

In order to investigate the importance of OxyR in the virulence of DC3000, we constructed an oxyR mutant $(\Delta o x y R)$. To complement $\triangle \operatorname{oxy} R$, we expressed the $\operatorname{oxy} R$ gene under the control of the native promoter, using a mini-Tn 5 system. The growth curve assay was carried out for DC3000 wild type (WT), $\triangle o x y R$, and the complemented line $(\Delta o x y R / o x y R)$ in King's B (KB) liquid media, and there were no significant differences between the bacterial growth among them (data not shown). It has been reported that $P$. aeruginosa OxyR has an important role in regulating the expression of the oxidative stress-response genes encoding the enzymes for ROS detoxification (Heo et al. 2010; Panmanee and Hassett 2009; Wei et al. 2012). To investigate the role of DC3000 OxyR in exogenous ROS detoxification, the $\mathrm{H}_{2} \mathrm{O}_{2}$ growth-inhibition assay was carried out with $\Delta o x y R$. As expected, $\Delta o x y R$ was the most susceptible to $\mathrm{H}_{2} \mathrm{O}_{2}$, showing reduced bacterial growth in $\mathrm{KB}$ media containing 1,5 , and $10 \% \mathrm{H}_{2} \mathrm{O}_{2}$ in comparison with WT and the complemented line (Fig. $1 \mathrm{~A}$ and $\mathrm{B}$ ), indicating that OxyR has a critical role in regulating the detoxification of exogenous ROS.

It is known that ROS are generated endogenously as a metabolic byproduct from intracellular reactions (Brynildsen et al. 2013). We next determined whether OxyR had an important role in detoxifying endogenous ROS. We tested $\Delta o x y R$ using a menadione growth-inhibition assay. Menadione is well-known to induce ROS generation via redox cycling and is used to mimic intracellular ROS stress in plant and animal species as well as bacterial systems (Brynildsen et al. 2013; Bulgakov et al. 2012; Guo et al. 2012; Ishikawa et al. 2010; Loor et al. 2010). As expected, $\Delta o x y R$ showed increased sensitivity to menadione, whereas DC3000 WT and $\Delta o x y R / o x y R$ did not (Fig. $1 \mathrm{~A}$ and $\mathrm{B}$ ), indicating that OxyR has a critical role in regulating endogenous ROS stress.

\section{OxyR is required for virulence of $P$. syringae $\mathrm{pv}$. tomato DC3000 in tomato and Arabidopsis.}

Plants have developed a surveillance immune system to protect themselves against attack by microbial pathogens. The oxidative burst is known as one of the earliest responses to microbial pathogens. The apoplastic ROS derived from NADPH oxidases, peroxidases, and glycolate oxidases are known to function as a second messenger by modulating signaling transduction, leading to defense responses such as the programmed cell death associated with the hypersensitive reaction (Bindschedler et al. 2006; Choi et al. 2007; Rojas et al. 2012; Torres et al. 2002; Yoshioka et al. 2003). The second messenger is not the only manner in which ROS function against microbial pathogen attack. ROS is also potentially toxic for microbial pathogens, including DC3000. Since our results demonstrated that OxyR had an important role in regulating ROS homeostasis, we next determined whether OxyR is important for the virulence of DC3000.

To assess the importance of OxyR in the virulence of DC3000, we challenged tomato and Arabidopsis with DC3000 WT, $\Delta o x y R$, and $\Delta o x y R / o x y R$ by flood inoculation (Ishiga et al. 2011; Uppalapati et al. 2008) and observed the disease progression. Both DC3000 WT and $\Delta$ oxyR/oxyR caused typical necrotic cell-death lesions with severe chlorosis on tomato seedlings at 6 days postinoculation (dpi) (Fig. 2A). On the other hand, tomato seedlings inoculated with $\triangle o x y R$ appeared healthy with reduced necrotic cell death and chlorosis (Fig. $2 \mathrm{~A})$. In tomato seedlings inoculated with $\Delta o x y R$, the bacterial populations were significantly lower compared with DC3000 WT and $\Delta o x y R / o x y R$ (Fig. 2B). Consistent with the results of disease symptoms and bacterial populations, lower ion leakage (a marker for disease-associated cell death) was observed in tomato seedlings infected with $\Delta o x y R$ compared with DC3000 WT and $\Delta o x y R / o x y R$ (Fig. 2C). DC3000 is pathogenic, not only to tomato but also to the model plant Arabidopsis thaliana (Ishiga et al. 2011). We next performed inoculation tests using Arabidopsis thaliana. Consistent with the results from tomato, Arabidopsis plants inoculated with both DC3000 WT and $\Delta o x y R / o x y R$ showed typical watersoaking lesions with severe chlorosis, whereas $\triangle$ oxy $R$ caused reduced disease symptoms at 3 dpi (Fig. 3A). The bacterial populations of $\triangle o x y R$ in the Arabidopsis plants were significantly lower compared with those of DC3000 WT and $\Delta$ oxyR/oxyR 
(Fig. 3B). Furthermore, a significant reduction in ion leakage was observed in Arabidopsis plants infected with $\Delta o x y R$ (Fig. $3 C)$. Taken together, these results clearly indicate that OxyR has a critical role in the virulence of DC3000 in tomato and Arabidopsis.

However, it is important to note that we eliminated epiphytic colonization of DC3000, using $5 \% \mathrm{H}_{2} \mathrm{O}_{2}$ to compare the internal bacterial populations. Therefore, one could argue that the reduced bacterial populations of the $\Delta o x y R$ mutant may result from the direct toxicity of $5 \% \mathrm{H}_{2} \mathrm{O}_{2}$ rather than from the reduced virulence of $\Delta o x y R$. To rule out this possibility, we carried out the bacterial growth studies for epiphytic and internal bacterial numbers without surface sterilization by $5 \% \mathrm{H}_{2} \mathrm{O}_{2}$. As shown in Supplementary Fig. $\mathrm{S} 2$, the bacterial populations of $\triangle \operatorname{oxy} R$ in the tomato and Arabidopsis plants were significantly lower compared with those of DC3000 WT and $\Delta o x y R / o x y R$. These results confirmed the effect of $5 \% \mathrm{H}_{2} \mathrm{O}_{2}$ is likely limited and the reduced bacterial populations of the $\triangle o x y R$ mutant may result from the reduced virulence of $\triangle o x y R$.
OxyR regulates the expression of thioredoxins and catalases in response to $\mathrm{H}_{2} \mathrm{O}_{2}$.

It has been reported that OxyR activates the transcription of target genes related to oxidative stress, such as thioredoxins, thioredoxin reductase, and catalases in animal pathogens (Charoenlap et al. 2005; Heo et al. 2010; Wei et al. 2012). Three thioredoxins (trx-1, trx-2, and $\operatorname{tr} x A)$, a thioredoxin reductase $(\operatorname{tr} x B)$, and three catalases $(k a t B, k a t E$, and $k a t G)$ were identified in the DC3000 genome. To investigate the expression profiles of these genes in response to ROS stress in DC3000 WT and $\triangle o x y R$, real-time quantitative reverse transcriptionpolymerase chain reaction (qRT-PCR) was performed using gene-specific primer sets. In this assay, bacteria were grown in mannitol-glutamate (MG) medium for $24 \mathrm{~h}$ and were then treated with $1 \mathrm{mM}, 100 \mu \mathrm{M}$, and $10 \mu \mathrm{M} \mathrm{H}_{2} \mathrm{O}_{2}$ for $15 \mathrm{~min}$. Our results demonstrated that the expression of genes including thioredoxin $(\operatorname{tr} x-2)$, thioredoxin reductase $(\operatorname{tr} x B)$, and catalases ( $k a t B$ and $k a t G$ ) was significantly induced within 15 min after treatment with $1 \mathrm{mM} \mathrm{H}_{2} \mathrm{O}_{2}$ in DC3000 WT but not in $\Delta o x y R$ (Fig. 4B, D, E and G), indicating that OxyR could positively
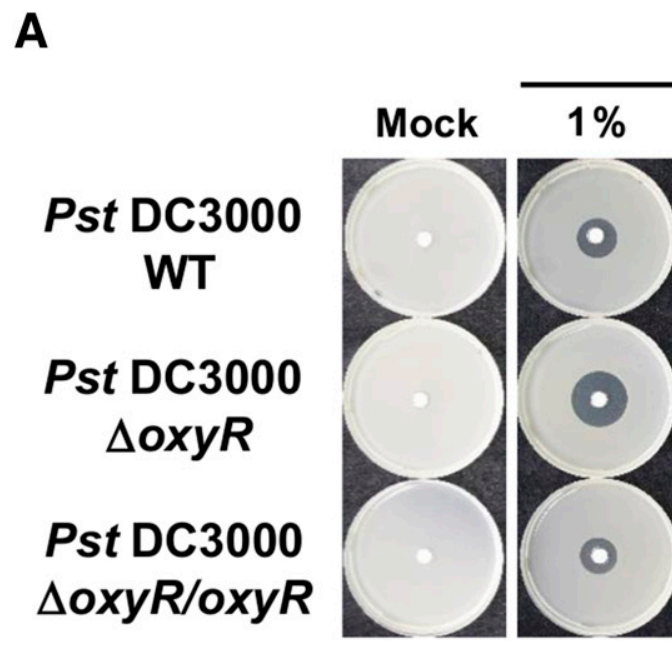

$\mathrm{H}_{2} \mathrm{O}_{2}$

$5 \% \quad 10 \%$
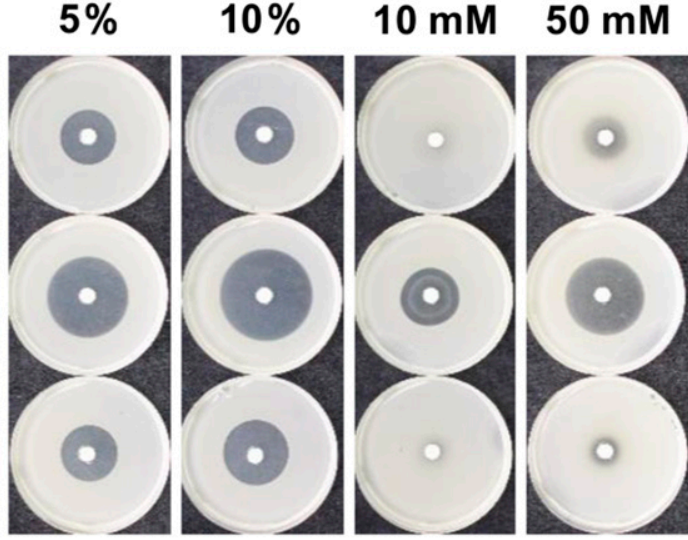

B

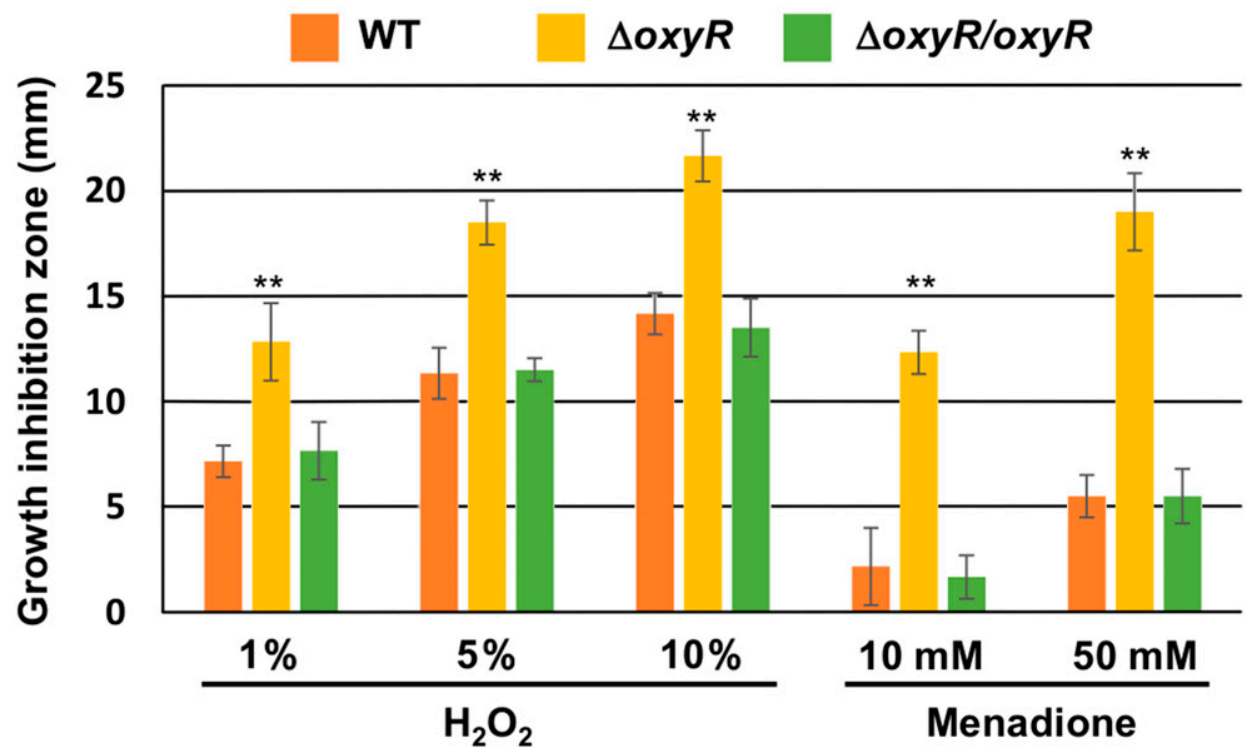

Fig. 1. Sensitivity of Pseudomonas syringae pv. tomato DC3000 (Pst DC3000) wild type (WT), the $\Delta$ oxyR mutant (Pst DC3000 $\Delta$ oxyR), and the complemented line (Pst DC3000 $\Delta$ oxyR/oxyR) to oxidative stresses. A, Growth inhibition on plates with 1, 5, and $10 \%$ of $\mathrm{H}_{2} \mathrm{O}_{2}$ and 10 and 50 mM of menadione. Photographs were taken at $24 \mathrm{~h}$ after incubation. B, Growth inhibition of each bacterial strain by 1,5 , and 10 of $\mathrm{H}_{2} \mathrm{O}_{2}$ and 10 and 50 mM of menadione. Diameters of bacterial growth were measured for each growth inhibition zone. Vertical bars indicate the standard error for three independent experiments. Each biological replicate contains two technical replicates. Asterisks indicate a significant difference from the DC3000 WT in a $t$ test $(* *<0.01)$. 
regulate the transcription of these genes. Interestingly, the induction of these genes was not observed in 100 and $10 \mu \mathrm{M}$ $\mathrm{H}_{2} \mathrm{O}_{2}$, suggesting that there may be activation thresholds in OxyR in response to $\mathrm{H}_{2} \mathrm{O}_{2}$. The expression of thioredoxin $(\operatorname{tr} x A)$ and catalase $(k a t E)$ was induced in response to $1 \mathrm{mM}$ $\mathrm{H}_{2} \mathrm{O}_{2}$ in DC3000 WT as well as in $\Delta o x y R$; however, these transcripts were differentially regulated in $\triangle o x y R$ (Fig. $4 \mathrm{C}$ and F). On the other hand, the expression of thioredoxin (tr $x-1)$ was slightly suppressed in response to $\mathrm{H}_{2} \mathrm{O}_{2}$ in DC3000 WT as well as in $\triangle \operatorname{oxy} R$ (Fig. 4A). Furthermore, our results revealed that the $\operatorname{oxy} R$ transcript was activated by the treatment with $\mathrm{H}_{2} \mathrm{O}_{2}$ (Fig. 4H). Together, these results suggest that $P$. syrinage OxyR could play an important role in regulating ROS stressresponsive genes.

\section{OxyR regulates the expression of catalases during the} infection of $P$. syringae pv. tomato $\mathrm{DC} 3000$ in Arabidopsis.

Since $\triangle o x y R$ impaired virulence, not only in tomato but also in Arabidopsis (Figs. 2 and 3), we next determined the expression profiles of the DC3000 genes involved in ROS stress during infection. In this assay, Arabidopsis wild-type Col-0 plants were inoculated with DC3000 WT or $\Delta o x y R$ for 24, 48, and $72 \mathrm{~h}$, and then, the total RNA, including plant and bacterial RNA, were purified for real-time qRT-PCR. The expression of the DC3000 genes was not detected in the Arabidopsis control plants without inoculation (data not shown). The expression of trx- 1 was slightly induced during the late infection stage of DC3000 WT; however, the $\operatorname{tr} x-1$ transcript was differentially regulated during $\triangle o x y R$ infection (Fig. 5A). The expression of $\operatorname{tr} x-2$ and $\operatorname{tr} x B$ was also differentially regulated in Arabidopsis plants inoculated with $\Delta o x y R$ (Fig. $5 \mathrm{~B}$ and D). There was no significant difference in the expression of $\operatorname{tr} x A$ between DC3000 WT and $\triangle o x y R$ (Fig. 5C). The expression of catalases (katB, katE, and katG) was induced during the late infection stage of DC3000 WT; however, the transcripts of these genes were lower in Arabidopsis plants inoculated with $\Delta o x y R$, in comparison with plants inoculated with DC3000 WT (Fig. 5E, $\mathrm{F}$, and $\mathrm{G})$. Interestingly, there was no induction of the katB transcript in Arabidopsis plants inoculated with $\triangle o x y R$ (Fig. $5 \mathrm{E})$. The $\operatorname{oxy} R$ was highly expressed in the plants inoculated with DC3000 WT, but its transcript was not detected with $\triangle \operatorname{oxyR}$ (Fig. 5H). These results suggest that OxyR could positively regulate the transcription of catalases during DC3000 infection.

\section{Loss-of-function of OxyR results in the altered expression of genes related to virulence.}

The T3SS and the phytotoxin COR play central roles in the pathogenesis of DC3000, by suppressing plant immunity and, also, by facilitating disease development in host plants (Buell et al. 2003). In order to investigate the importance of OxyR in the regulation of genes related to virulence, we analyzed the
A

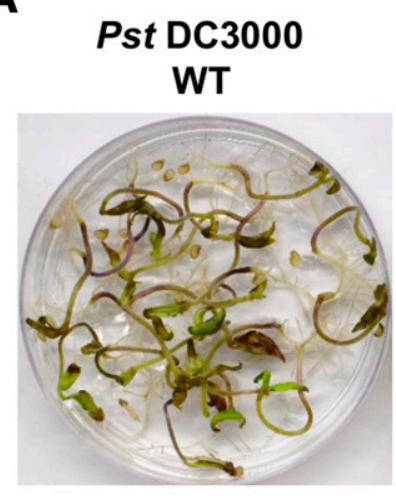

B

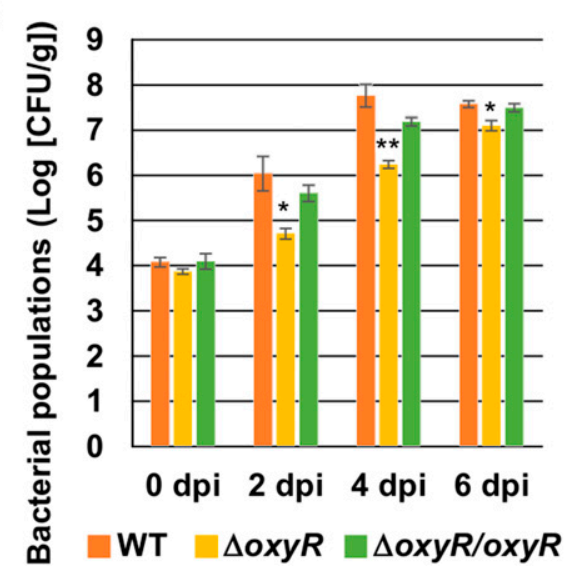

Pst DC3000 $\Delta \mathrm{oxyR}$

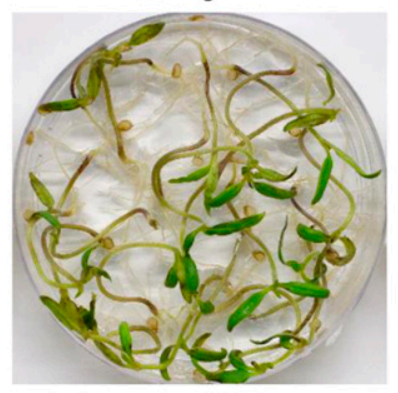

C

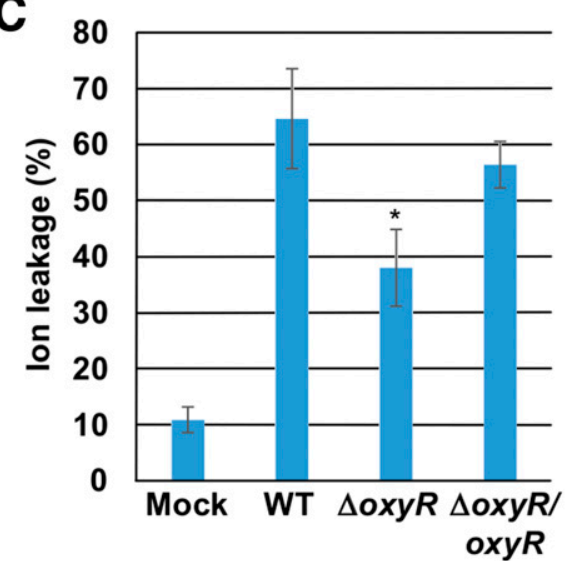

Fig. 2. Disease symptoms in tomato cv. Glamour flood-inoculated with Pseudomonas syringae pv. tomato DC3000 (Pst DC3000) wild type (WT), the $\Delta$ oxyR mutant (Pst DC3000 $\Delta$ oxyR), and the complemented line (Pst DC3000 $\Delta$ oxyR/oxyR). Four-day-old tomato seedlings were inoculated and then the bacterial populations and ion leakage were observed. A, Disease symptoms in tomato seedlings flood-inoculated with WT, $\Delta$ oxy $R$, and $\Delta o x y R / o x y R$ at $2 \times 10^{7} \mathrm{CFU} / \mathrm{ml}$. Photographs were taken at 6 days postinoculation (dpi). B, Bacterial population dynamics in tomato seedlings inoculated with DC 3000 WT, $\Delta o x y R$, and $\triangle$ oxyR/oxyR at $2 \times 10^{7} \mathrm{CFU} / \mathrm{ml}$. The bacterial populations were obtained by homogenizing the inoculated leaves after surface-sterilization, then plating dilutions to selective media at 0,2, 4, and 6 days postinoculation (dpi). Vertical bars indicate the standard error for three independent experiments. Asterisks indicate a significant difference from WT in a $t$ test $(*<0.05 ; * *<0.01)$. C, Ion leakage from tomato seedlings after treatment with water (mock) or inoculation with WT, $\Delta o x y R$, and $\Delta o x y R / o x y R$ at $2 \times 10^{7} \mathrm{CFU} / \mathrm{ml}$; measurements were taken at 6 dpi. Values show the percentage of total ions. Vertical bars indicate the standard error for three independent experiments. Asterisks indicate a significant difference from WT in a $t$ test $(*<0.05)$. 
expression profiles of genes encoding transcriptional regulators of the T3SS and the COR biosynthesis genes, including hrpL and $\operatorname{corR}$, respectively. The expression of $h r p L$ and $\operatorname{cor} R$ was clearly suppressed in response to $1 \mathrm{mM} \mathrm{H}_{2} \mathrm{O}_{2}$; however, there was no significant difference between the expression levels of these genes for DC3000 WT and $\triangle o x y R$ (Fig. 6A and 6C). Interestingly, the expression of $h r p L$ and $\operatorname{corR}$ was slightly induced in response to $10 \mu \mathrm{M} \mathrm{H}_{2} \mathrm{O}_{2}$ in DC3000 WT but not in $\triangle \operatorname{oxyR}$ (Fig. 6A and C). Moreover, there were no significant differences in the expression of $h r p L$ and corR between DC3000 WT and $\triangle o x y R$ during infection (Fig. 6B and D). These results suggest that OxyR may partially function in modulating the expression of the T3SS and the COR biosynthesis genes.

In addition to the T3SS and COR, some studies have shown that the exopolysaccharide (EPS) alginate, a copolymer of mannuronic and guluronic acids, functions in the virulence of $P$. syringae (Osman et al. 1986; Yu et al. 1999). ROS were demonstrated to function as a signal for the activation of the alginate biosynthesis gene $\operatorname{alg} D$ in DC3000 (Keith et al. 2003). In order to investigate the function of OxyR in alginate production in DC3000, we carried out an expression analysis of $\operatorname{alg} D$. The $\operatorname{alg} D$ transcript was slightly induced in response to $1 \mathrm{mM} \mathrm{H}_{2} \mathrm{O}_{2}$ in DC3000 WT and $\triangle \operatorname{oxyR}$ (Fig. 6E) and accumulated during the late stage of DC3000 infection. Moreover, these transcripts were differentially regulated in Arabidopsis plants inoculated with $\triangle \operatorname{oxy} R$ (Fig. 6F). These results suggest that OxyR may have an indirect effect in the regulation of $\operatorname{alg} D$ through its effect on bacterial growth and survival during the late stage of DC3000 infection.
The $\Delta o x y R$ mutant displays full virulence on the Arabidopsis sid2 mutant.

The interactions between Pseudomonas syringae and Arabidopsis have been utilized to investigate the molecular basis of plant defense responses against pathogens and have revealed a number of key regulators for signaling pathways (Chisholm et al. 2006; Gimenez-Ibanez and Rathjen 2010; Ishiga et al. 2011; Macho and Zipfel 2014; Xin and He 2013). The salicylic acid (SA)-mediated signaling pathway leading to defense responses is known to function against a wide range of biotrophic and hemibiotrophic pathogens (Pieterse et al. 2012; RobertSeilaniantz et al. 2011). In order to investigate the virulence of $\triangle o x y R$ on Arabidopsis mutants compromised in defense signaling pathways, we utilized mutant lines of sid2, eds1, pad4, and $r b o h D$, as well as $N a h G$ transgenic lines. Interestingly, bacterial growth revealed that the sid 2 mutant showed enhanced susceptibility to the $\Delta o x y R$ mutant, whereas other lines showed comparable bacterial populations to those in the wildtype Col-0 (Supplementary Fig. S3). Based on these results, we focused on the sid 2 mutant for further analysis. The sid 2 mutant showed enhanced chlorotic disease symptoms, not only to DC3000 WT but also to the $\Delta o x y R$ mutant (Fig. 7A). Moreover, the $\triangle o x y R$ mutant could multiply to almost the same levels when compared with DC3000 WT (Fig. 7B), indicating that the $\triangle o x y R$ mutant displays full virulence on the Arabidopsis sid2 mutant.

\section{DISCUSSION}

In this study, we conducted the functional analysis of OxyR and found that OxyR plays an important role in the virulence of
A

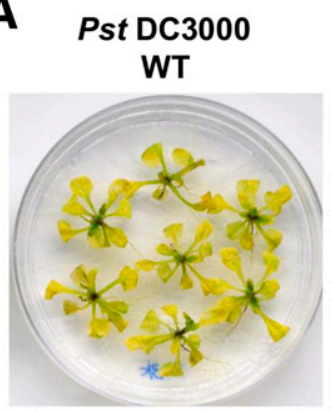

B

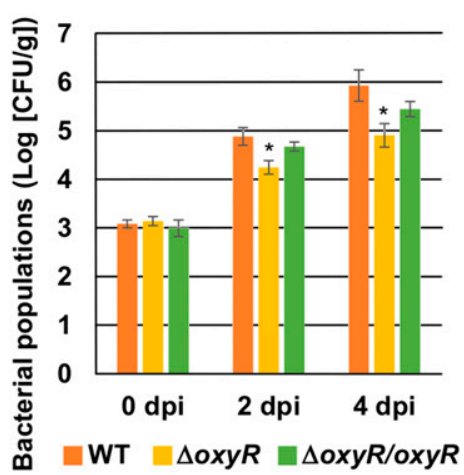

Pst DC3000 $\triangle \mathrm{OxyR}$

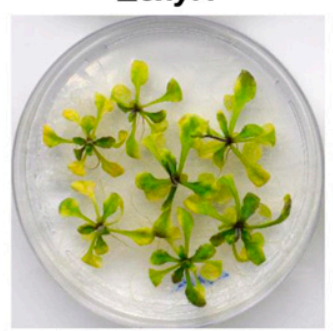

C

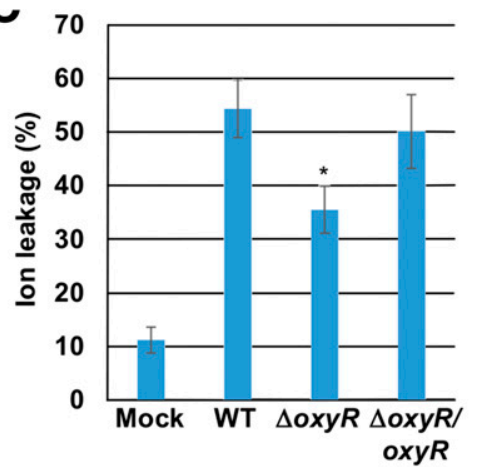

Fig. 3. Disease symptoms in Arabidopsis plants flood-inoculated with Pseudomonas syringae pv. tomato DC3000 (Pst DC3000) wild type (WT), the $\Delta$ oxyR mutant (Pst DC3000 $\Delta$ oxyR), and the complemented line (Pst DC3000 $\Delta$ oxyR/oxyR). Two-week-old Arabidopsis plants were inoculated and the bacterial populations and ion leakage were observed. A, Disease symptoms in Arabidopsis plants flood-inoculated with WT, $\Delta o x y R$, and $\Delta o x y R / o x y R$ at $5 \times 10^{6} \mathrm{CFU} / \mathrm{ml}$. Photographs were taken at 3 days postinoculation (dpi). B, Bacterial population dynamics in Arabidopsis plants inoculated with WT, $\Delta o x y R$, and $\Delta o x y R / o x y R$ at $5 \times 10^{6} \mathrm{CFU} / \mathrm{ml}$. Bacterial populations were obtained by homogenizing the inoculated leaves after surface-sterilization and plating dilutions to selective media at 0,2 , and $4 \mathrm{dpi}$. Vertical bars indicate the standard error for three independent experiments. Asterisks indicate a significant difference from WT in a $t$ test $(*<0.05)$. C, Ion leakage from Arabidopsis plants after treatment with water (mock) or inoculation with WT, $\Delta o x y R$, and $\Delta o x y R / o x y R$ at $5 \times 10^{6} \mathrm{CFU} / \mathrm{ml}$; measurements were taken at $3 \mathrm{dpi}$. The values show the percentage of total ions. Vertical bars indicate the standard error for three independent experiments. Asterisks indicate a significant difference from WT in a $t$ test $(*<0.05)$. 
A

C
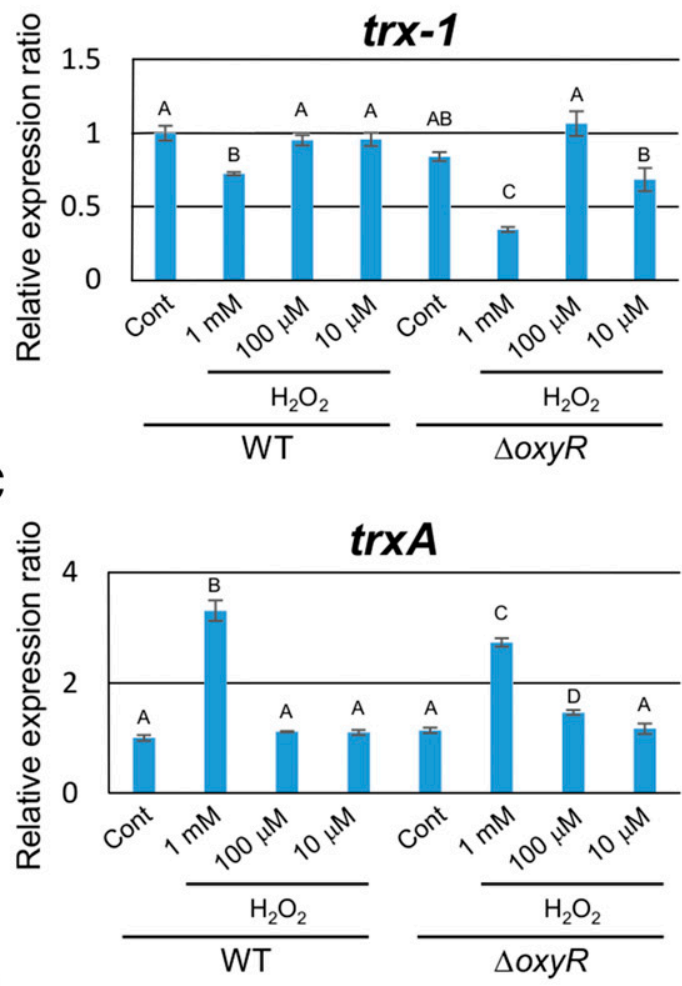

$\mathbf{E}$

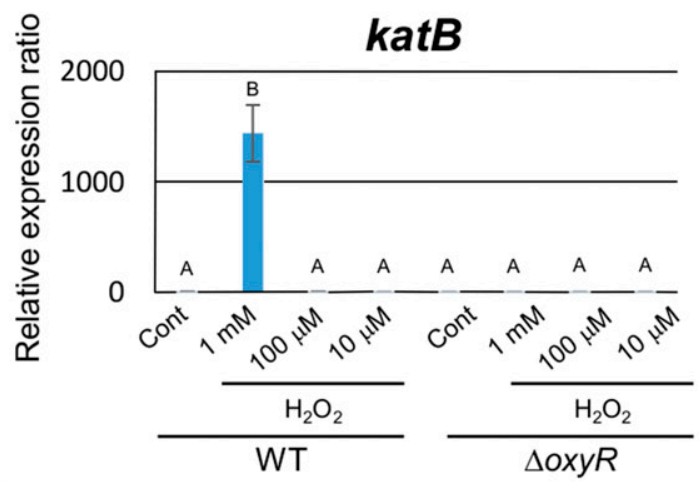

G

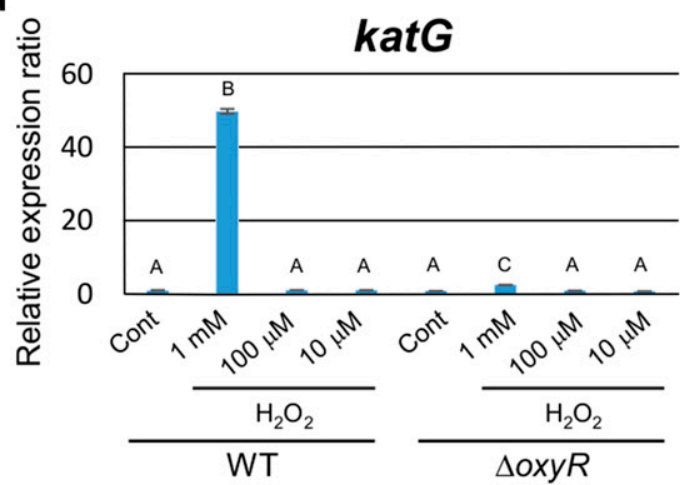

B

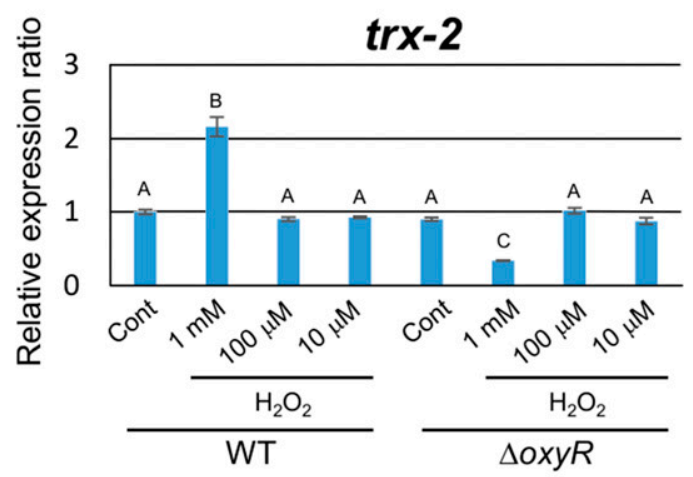

D

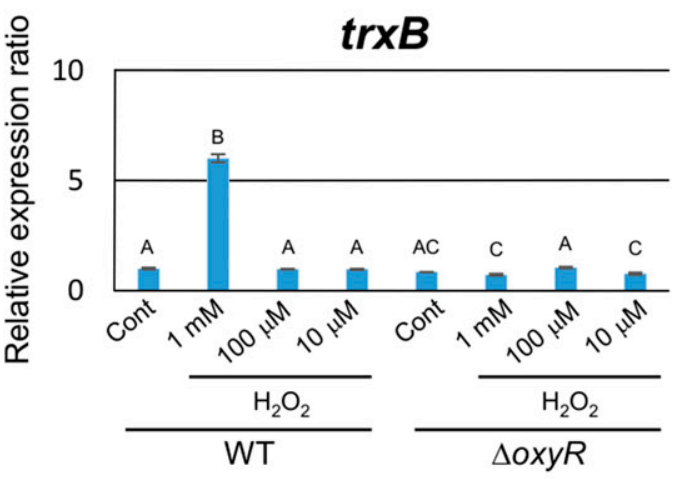

$\mathbf{F}$

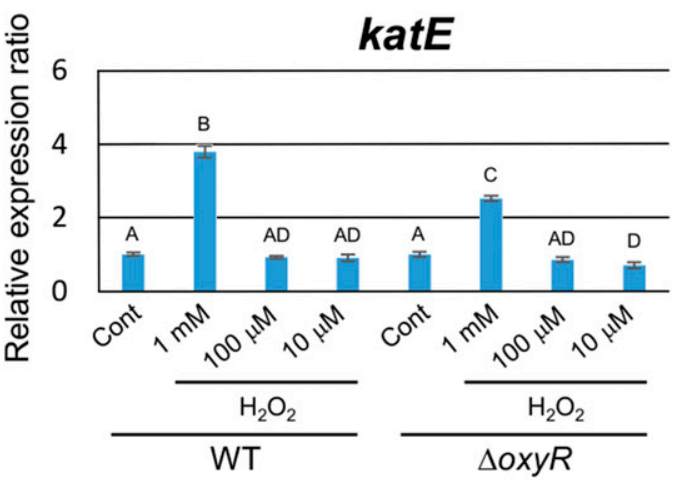

$\mathbf{H}$

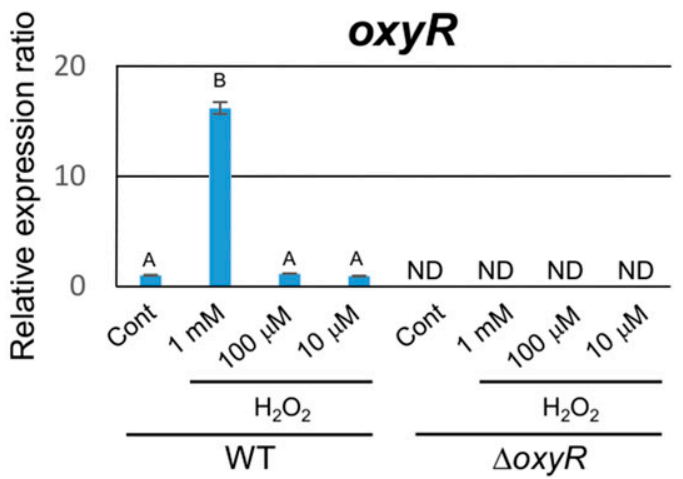

Fig. 4. Expression profiles of genes involved in reactive oxygen species detoxification of Pseudomonas syringae pv. tomato DC3000 wild type (WT) and the $\triangle$ oxyR mutant $(\triangle o x y R)$ in response to $\mathrm{H}_{2} \mathrm{O}_{2}$. WT and $\Delta$ oxyR were grown in mannitol-glutamate medium to an optical density at $600 \mathrm{~nm}$ of 0.2 , and $\mathrm{H}_{2} \mathrm{O}_{2}$ was added to a final concentration of $1 \mathrm{mM}, 100$, and $10 \mu \mathrm{M}$. The gene expression of selected DC3000 genes were normalized with three housekeeping genes including oprI, proC, and rpoD at 15 min after treatment with $\mathrm{H}_{2} \mathrm{O}_{2}$ by quantitative reverse transcription-polymerase chain reaction (qRT-PCR) with genespecific primer sets. The expression profiles are presented for genes encoding $\mathbf{A}$, thioredoxins $\operatorname{trx}-1, \mathbf{B}, \operatorname{trx}-2$, and $\mathbf{C}, \operatorname{tr} x A ; \mathbf{D}$, thioredoxin reductase $\operatorname{trx} B$; $\mathbf{E}$, catalases $k a t B, \mathbf{F}, k a t E$, and $\mathbf{G}, k a t G$; and $\mathbf{H}$, oxyR. Vertical bars indicate the standard error for three biological replicates. Statistically significant differences are noted with different letters based on analysis of variance $(P<0.05)$. ND indicates not detected by qRT-PCR. 
A

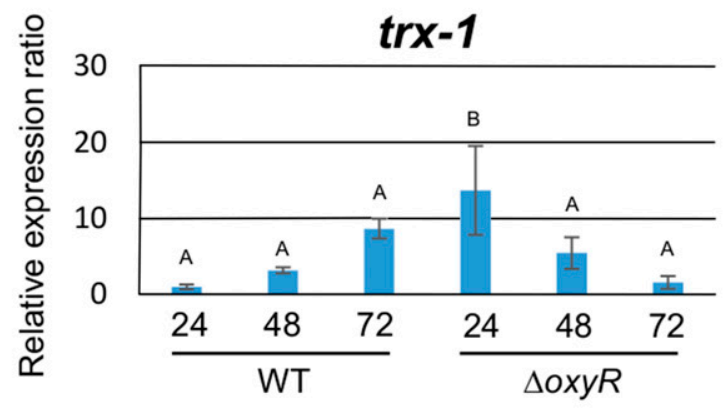

C

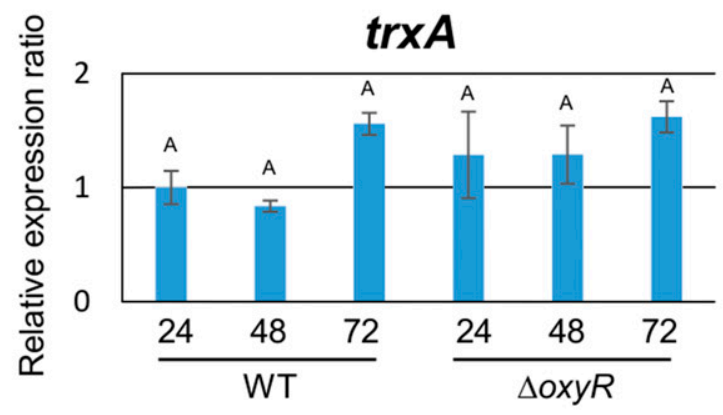

E

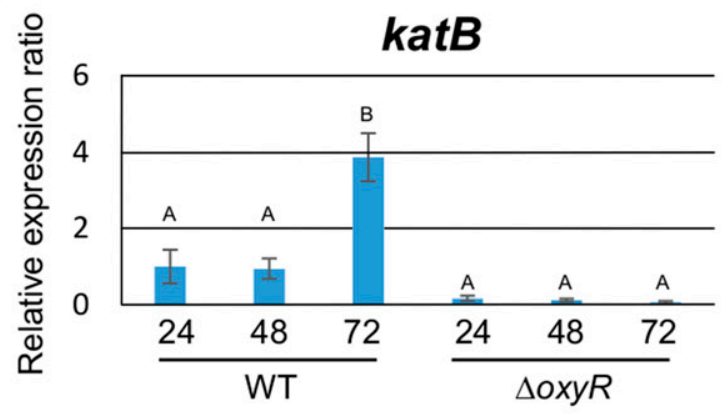

G

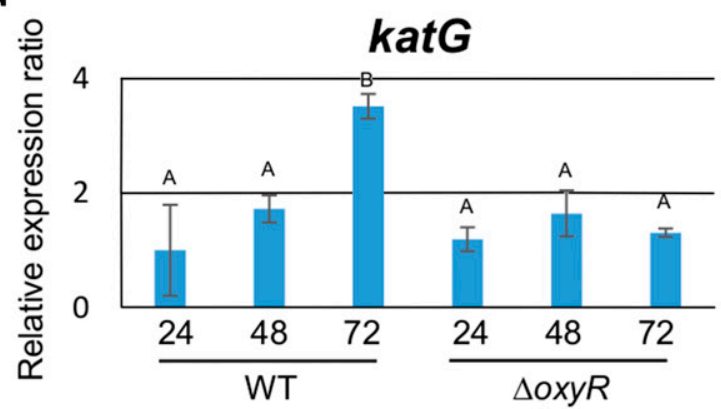

B

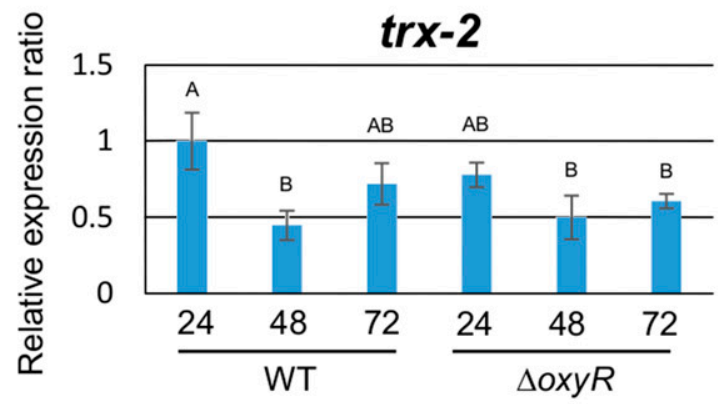

D

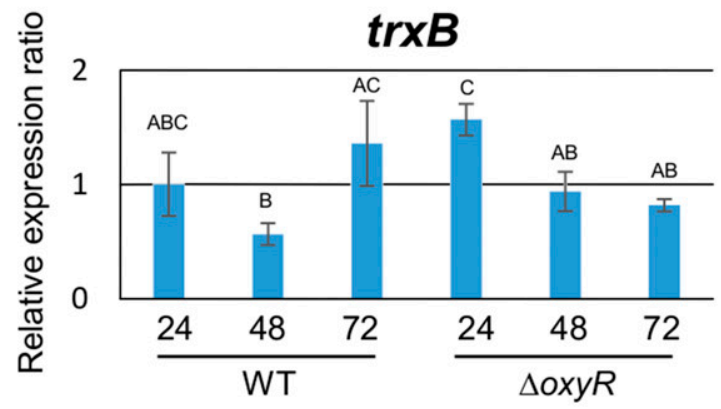

F

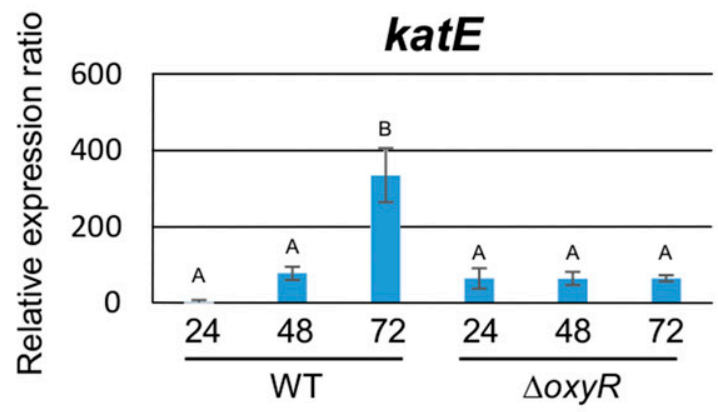

H

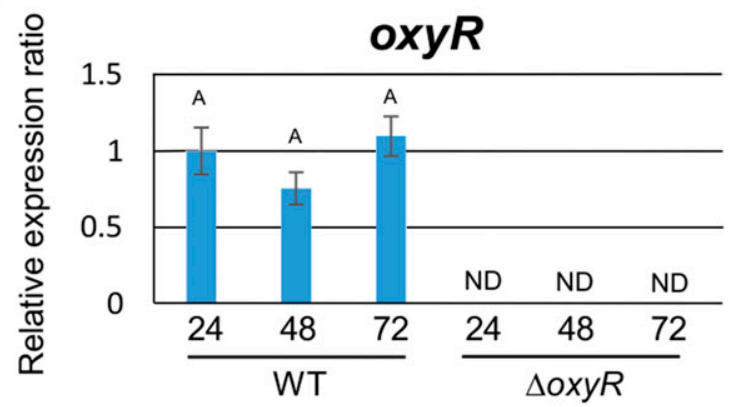

Fig. 5. Expression profiles of genes involved in reactive oxygen species detoxification of Pseudomonas syringae pv. tomato DC3000 wild type (WT) and the $\Delta o x y R$ mutant during Arabidopsis infection. Two-week-old Arabidopsis plants were inoculated with WT and $\Delta o x y R$ at $5 \times 10^{6} \mathrm{CFU} / \mathrm{ml}$, and the inoculated plants were fixed at 24,48 , and $72 \mathrm{~h}$ postinoculation, for total RNA isolation. The gene expression of selected DC3000 genes was determined by quantitative reverse transcription-polymerase chain reaction (qRT-PCR) with gene-specific primer sets. The gene expression profiles were normalized with three housekeeping genes including oprI, proC, and rpoD. The expression profiles are presented for genes encoding $\mathbf{A}$, thioredoxins $\operatorname{tr} x$ - 1 , $\mathbf{B}$, trx -2 , and $\mathbf{C}$, trx $A ; \mathbf{D}$, thioredoxin reductase $\operatorname{tr} x B ; \mathbf{E}$, catalases $k a t B, \mathbf{F}, k a t E$, and $\mathbf{G}, k a t G$; and $\mathbf{H}$, oxyR. Vertical bars indicate the standard error for three biological replicates. Statistically significant differences are noted as different letters based on analysis of variance $(P<0.05)$. ND indicates not detected by qRT-PCR. 
DC3000 in tomato and Arabidopsis (Figs. 2 and 3). Furthermore, we confirmed that the $\Delta o x y R$ mutant showed increased susceptibility to oxidative stress relative to the DC3000 WT (Fig. 1). Gene expression profiles indicated that katB, katE, $k a t G$, and $o x y R$ itself were differentially expressed in the $\Delta o x y R$ mutant background and in response to $\mathrm{H}_{2} \mathrm{O}_{2}$, suggesting that OxyR is necessary for $\mathrm{H}_{2} \mathrm{O}_{2}$-inducible gene expression. Based on the gene-expression studies shown in Figures 4 and 5 , it is tempting to speculate that OxyR could directly regulate the expression of $k a t B$ and $k a t G$ during oxidative stress conditions and that KatB and KatG may have crucial roles during DC30000 infection. Interestingly, similar results were observed in a DC3000 catalase mutant analysis wherein katB and katG mutants showed a reduction in bacterial growth in planta compared with DC3000 (Guo et al. 2012). Furthermore, katB and $k a t G$ were demonstrated to contribute the most against oxidative stress, based on the katB and $k a t G$ mutants having exhibited more susceptibility to $\mathrm{H}_{2} \mathrm{O}_{2}$ than the katE mutant
A

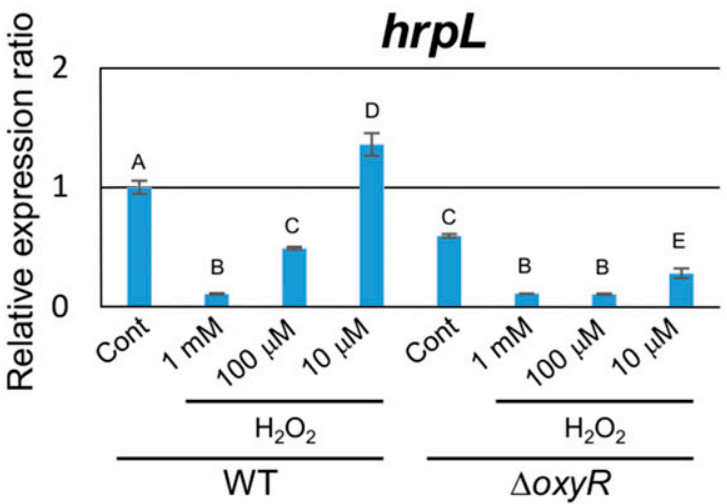

C

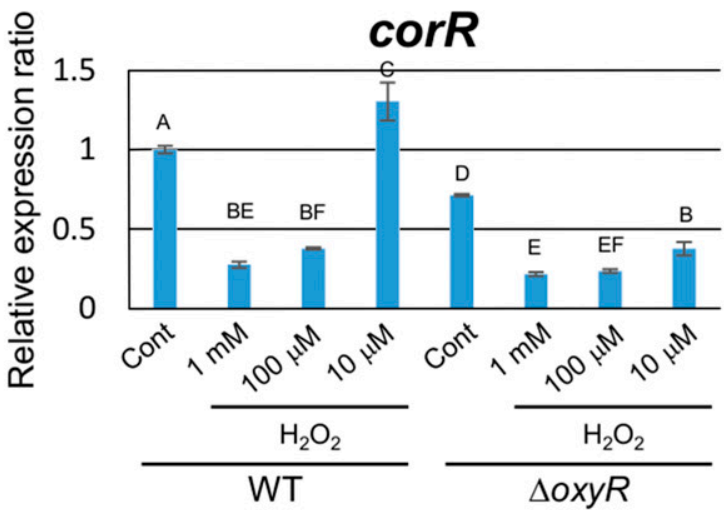

E

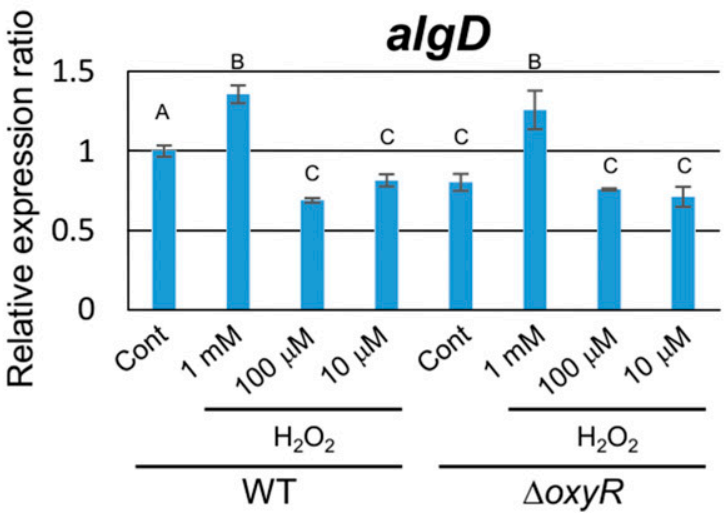

B

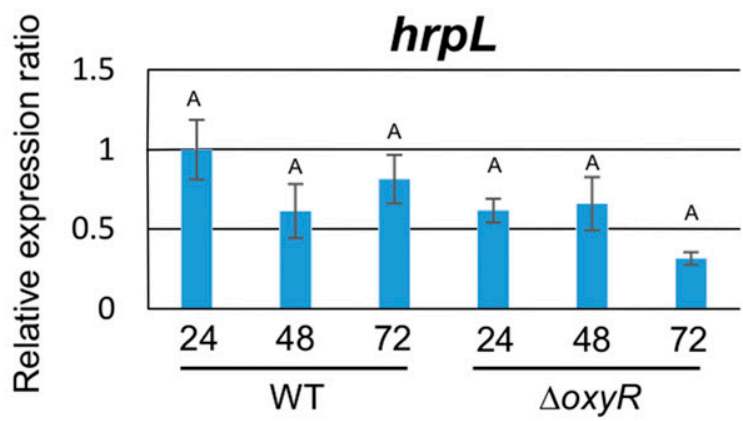

D

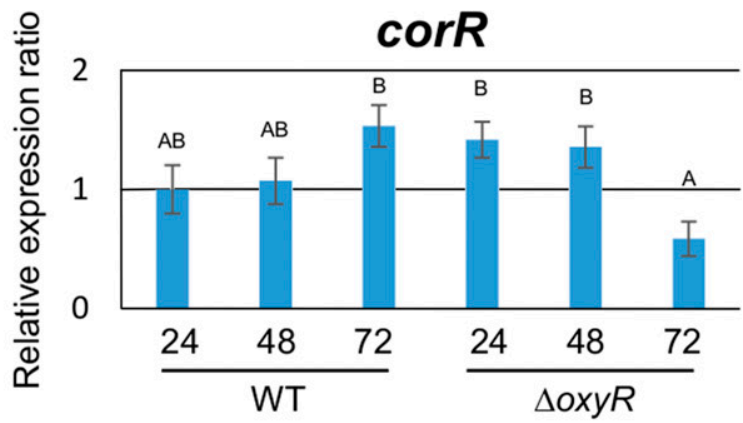

$\mathbf{F}$

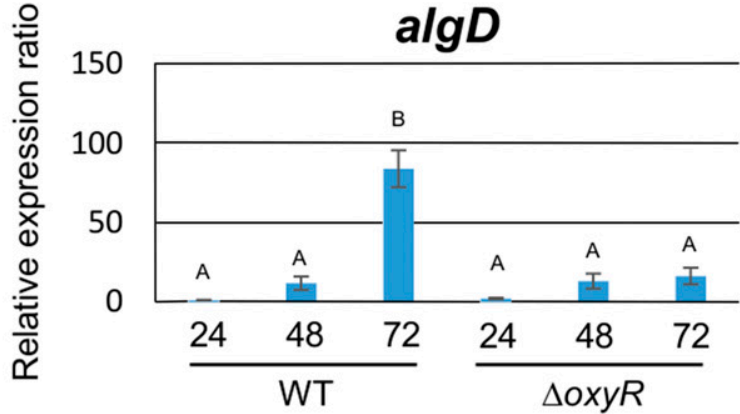

Fig. 6. Expression profiles of genes involved in the virulence of Pseudomonas syringae pv. tomato $\mathrm{DC} 3000$ and the $\Delta$ oxyR mutant in response to $\mathrm{H}_{2} \mathrm{O}_{2}$ or during Arabidopsis infection. DC3000 and $\Delta o x y R$ were grown in mannitol-glutamate medium to an $\mathrm{OD}_{600}$ of 0.2 , and $\mathrm{H}_{2} \mathrm{O}_{2}$ was added to a final concentration of $1 \mathrm{mM}, 100$, and $10 \mu \mathrm{M}$. The gene expression of selected DC3000 genes was determined at 15 min after treatment with $\mathrm{H}_{2} \mathrm{O}_{2}$ by quantitative reverse transcriptionpolymerase chain reaction (qRT-PCR) with gene-specific primer sets. The gene expression profiles were normalized with three housekeeping genes including oprI, proC, and rpoD. Two-week-old Arabidopsis plants were inoculated with DC 3000 and $\Delta$ oxyR at $5 \times 10^{6} \mathrm{CFU} / \mathrm{ml}$ and the inoculated plants were fixed at 24,48 , and $72 \mathrm{~h}$ postinoculation, for total RNA isolation. The gene expression of select DC3000 genes was determined by qRT-PCR with gene-specific primer sets. The expression profiles are presented for genes including $\mathbf{A}$ and $\mathbf{B}, h r p L, \mathbf{C}$ and $\mathbf{D}, \operatorname{corR}$, and $\mathbf{E}$ and $\mathbf{F}$, algD. Vertical bars indicate the standard error for three biological replicates. Statistically significant differences are noted with different letters based on analysis of variance $(P<0.05)$. 
(Guo et al. 2012). These results suggest that OxyR-mediated activation of $k a t B$ and $k a t G$ may play an important role, not only in oxidative stress responses but also in the virulence of DC3000. Gene expression profiles revealed that genes encoding ROS-detoxifying enzymes including thioredoxin, thioredoxin reductase, and catalase were up-regulated during oxidative-stress conditions or DC3000 infection. In addition to these genes, we also demonstrated that the expression of genes related to the virulence of DC3000 was differentially regulated during oxidative-stress conditions. Interestingly, the expression of $h r p L$ and corR was clearly down-regulated in response to $1 \mathrm{mM} \mathrm{H}_{2} \mathrm{O}_{2}$ (Fig. 6). Moreover, the expression of these genes was slightly induced in response to $10 \mu \mathrm{M} \mathrm{H}_{2} \mathrm{O}_{2}$ (Fig. 6). It has been reported that HrpL, an alternative sigma factor, regulates the expression of the Hrp regulon (T3SS genes) by its binding to a promoter sequence called the Hrp box (Ferreira et al. 2006; Fouts et al. 2002; Lam et al. 2014). Since
HrpL is known to activate sets of virulence genes, tomato leaves inoculated with a $h r p L$ mutant of DC3000 were symptomless (Sreedharan et al. 2006). Thus, it appears that high levels of apoplastic ROS derived from the oxidative burst may function not only as a direct toxic compound against invading bacterial pathogens but, also, as a negative regulator for virulence factors, including the T3SS genes.

Moreover, we also revealed the correlation between functional OxyR and the induction of algD (Fig. 6). Several studies have shown that alginate plays an important role in the virulence of $P$. syringae. In bean leaves inoculated with an alginatedefective mutant of $P$. syringae pv. syringae, disease symptoms and bacterial populations were significantly reduced compared with the WT (Yu et al. 1999). Gene expression analysis of algD in the compatible interaction between DC3000 and tomato showed that the induction of $\operatorname{alg} D$ was only detected in the leaves showing necrotic cell death (Keith et al. 2003).

A Col-0 WT sid2-2

\section{Pst DC3000 WT}
Pst DC3000 $\Delta \mathrm{oxyR}$
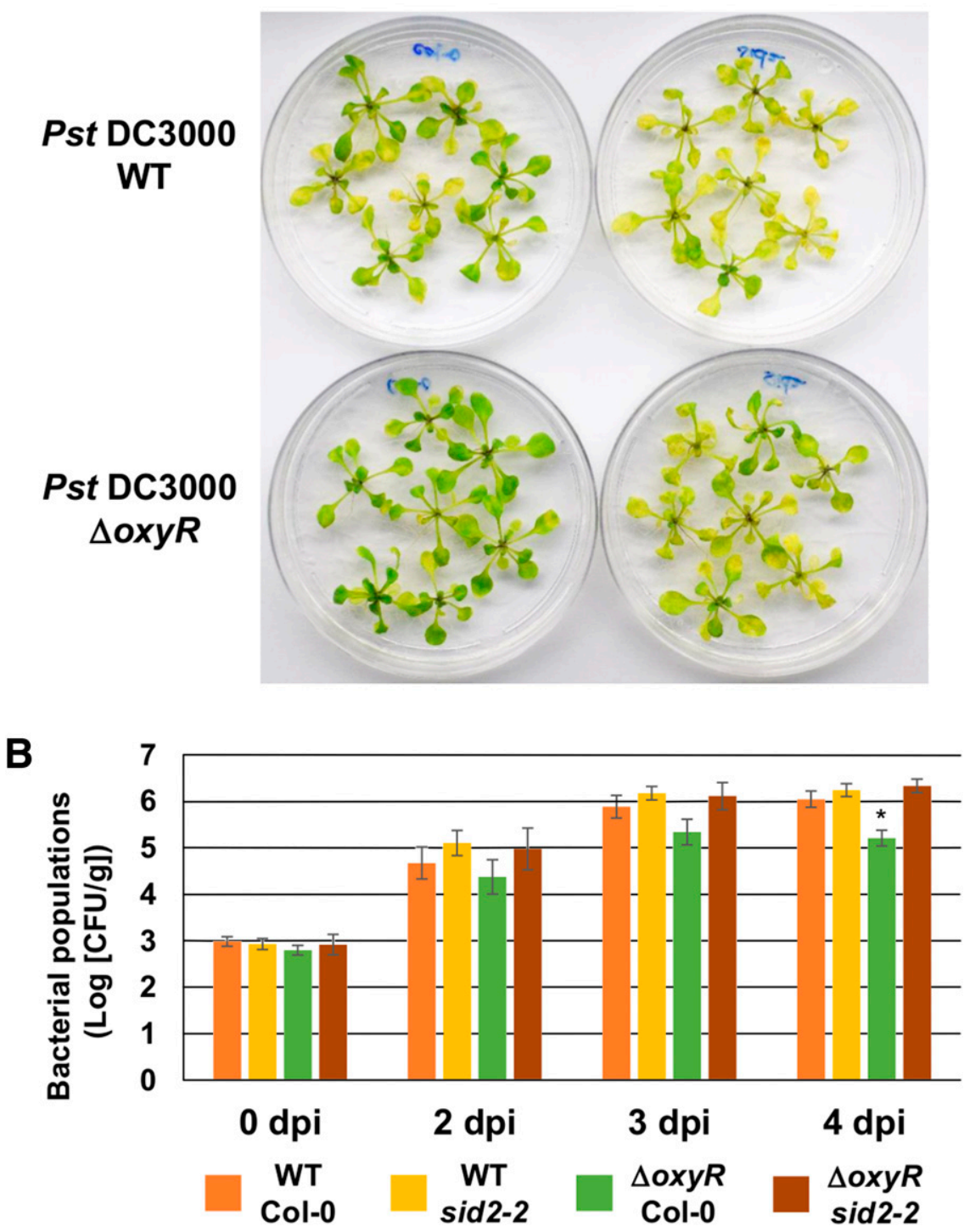

Fig. 7. Disease symptoms in the Arabidopsis sid2 mutant flood-inoculated with Pseudomonas syringae pv. tomato DC3000 wild type (WT) and the $\Delta$ oxyR mutant $(\Delta o x y R)$. Two-week-old WT Arabidopsis Col-0 and the sid2 mutant were inoculated, and the bacterial populations were measured. A, Disease symptoms in the wild-type Arabidopsis Col-0 and the sid 2 mutant flood-inoculated with DC3000 WT and $\Delta$ oxyR at $5 \times 10^{6} \mathrm{CFU} / \mathrm{ml}$. Photographs were taken at 3 days postinoculation (dpi). B, Bacterial population dynamics in the wild-type Arabidopsis Col-0 and the sid 2 mutant inoculated with DC 3000 WT and $\Delta o x y R$ at $5 \times 10^{6} \mathrm{CFU} / \mathrm{ml}$. The bacterial populations were obtained by homogenizing the inoculated leaves after surface-sterilization and plating dilutions to selective media at $0,2,3$, and $4 \mathrm{dpi}$. Vertical bars indicate the standard error for three independent experiments. Asterisks indicate a significant difference from the WT Col-0 in a $t$ test $(*<0.05)$. 
Consistently, the expression of $\operatorname{alg} D$ was also induced in the late stage of DC3000 infection in Arabidopsis, suggesting that alginate may play an important role in the pathogenicity of DC3000, especially in modulating disease-associated necrotic cell death. It has been demonstrated that high levels of ROS, including both apoplastic and chloroplastic ROS, are generated in the late stages of DC3000 infection and that ROS production is required for modulating disease-associated necrotic cell death (Ishiga et al. 2009). Arabidopsis plants lacking functional NADPH-dependent thioredoxin reductase C (NTRC), a central regulator involved in detoxifying chloroplast ROS, showed enhanced ROS accumulation, resulting in severe diseaseassociated necrotic cell death after inoculation with DC3000. However, the reduction of bacterial populations by ROS toxicity was not found in the ntrc mutant, as the bacterial populations were the same between the wild-type and the ntrc mutant (Ishiga et al. 2009), suggesting that DC3000 might modulate ROS levels by virulence factors, including alginate and ROS-detoxifying enzymes regulated by OxyR. Furthermore, $\triangle$ oxyR mutant studies in Pantoea stewartii subsp. stewartii, a causal agent of Stewart's wilt of sweet corn, demonstrated that OxyR was required for EPS production and the induction of wilting symptoms (Burbank and Roper 2014). Thus, it is tempting to speculate that alginate together with ROS-detoxifying enzymes play a critical role in the late stages of infection, especially the formation of disease-associated necrotic cell death.

Several genes have been identified whose expression is differently regulated between DC3000 WT and the $\Delta o x y R$ mutant under oxidative-stress conditions or during DC3000 infection (Figs. 4, 5, and 6). These genes include $\operatorname{trx}-1, \operatorname{tr} x-2, \operatorname{tr} x A, \operatorname{tr} x B$, katB, katE, katG, hrpL, corR, and $\operatorname{algD}$. To date, there is no evidence that OxyR directly binds to the promoter of any of these genes and regulates the expression. However, Wei et al. (2012) reported that an in silico approach for the DC3000 genome could predict the OxyR binding motif in the promoter regions of the $\operatorname{tr} x-1, \operatorname{tr} x-2, \operatorname{tr} x B$, and $k a t B$ genes, suggesting that these genes could be probable direct transcriptional targets of OxyR, and the differential expression of other genes including $\operatorname{trxA}$, katE, katG, hrpL, corR, and algD could be due to the cascade of indirect consequences of an $\operatorname{oxy} R$ mutation. Based on the expression profiles of katE, hrpL, corR, and $\operatorname{algD}$ in Figures 5 and 6, it is possible that OxyR may have an indirect effect in the regulation of virulence genes through its effect on bacterial growth and survival.

The sid 2 mutant and NahG transgenic line have been utilized as model mutants with abolished SA synthesis and accumulation, respectively (Love et al. 2007; Makandar et al. 2010; Massoud et al. 2012). EDS1 (enhanced disease susceptibility 1) and PAD4 (phytoalexin deficient 4) encoding lipase-like proteins are known to have essential functions in ETI and plant basal resistance to virulent pathogens and contribute to SA production (Rietz et al. 2011; Wiermer et al. 2005). In this study, we revealed that the $\triangle o x y R$ mutant displayed full virulence on the sid2 mutant but not on the $N a h G$ transgenic line and the pad4 and eds 1 mutant lines. One possibility to explain the enhanced susceptibility of the sid2 lines against the $\Delta o x y R$ mutant is the multiple functions of SID2. SID2 encodes isochorismate synthese 1 (ICS1), which functions as a crucial enzyme in the SA synthesis pathway. However, SID2/ICS1 is also known to function in the synthesis of phylloquinone, which has an important role in the photosynthetic electron-transport chain in plants. Recent studies indicated that ICS1 has a critical role, not only for plant immunity but also for light acclimation, by regulating the redox state of the plastoquinone pool and the adaptation of photosynthesis (Gawroński et al. 2013). The importance of chloroplasts in plant immunity has been reported
(Nomura et al. 2012). Furthermore, recent studies demonstrated that the sid2 mutant was impaired in the PAMP-triggered oxidative burst (Yi et al. 2014). Together with our results, it is tempting to speculate that the loss-of-function of plant immunity in the sid2 mutant, including the oxidative burst as well as redox regulation in chloroplasts, may enable the $\Delta o x y R$ mutant to display full virulence.

It is known that $E$. coli and $P$. aeruginosa utilize two major redox-sensing transcriptional regulators under oxidative-stress conditions, including SoxR and OxyR (Kobayashi and Tagawa 2004; Pomposiello and Demple 2001; Wei et al. 2012). Surprisingly, DC3000 contains OxyR but not SoxR, and wholegenome sequence studies of other $P$. syringae pathovars have revealed that there are no ORFs encoding putative protein homologs to the E. coli and $P$. aeruginosa SoxR. P. putida also maintains functional SoxR and OxyR in the genome. However, additional regulators including FinR and HexR have been reported to regulate numerous genes under oxidative-stress conditions in P. putida (Kim and Park 2014; Yeom et al. 2010). Interestingly, the ORFs encoding putative homologs to P. putida FinR and HexR are present in the genome of DC3000. Furthermore, OxyR has been demonstrated to respond to nitric oxide and function as a master regulator of $S$-nitrosylation in E. coli. (Seth et al. 2012). Therefore, further identification of transcriptional regulators that function under oxidative-stress conditions and characterization of their modes of action in conjunction with OxyR are needed to understand the mechanisms of ROS-mediated interactions between plant and bacterial pathogens.

\section{MATERIALS AND METHODS}

\section{Plant materials and growth conditions.}

Tomato (Solanum lycopersicum cv. Glamour) seedling assays and Arabidopsis flood-inoculation were used for the pathogen assay. Briefly, tomato and Arabidopsis thaliana seeds were germinated and were maintained on one-half Murashige and Skoog medium (0.3\% phytagel) with Gamborg vitamins (Sigma-Aldrich, St. Louis). Tomato seedlings were used for pathogen assays 4 days after germination at $24^{\circ} \mathrm{C}$ in darkness. Arabidopsis thaliana ecotype Colombia (Col-0) was used as a wild-type plant in this study. Arabidopsis thaliana plants were incubated at $24^{\circ} \mathrm{C}$, with a light intensity of $200 \mu \mathrm{E} \mathrm{m}^{-2} \mathrm{~s}^{-1}$ and a 12-h-light and 12-h-dark photoperiod and, at 2 weeks postgermination, the seedlings were used for the pathogen assays.

\section{Bacterial strains and growth conditions.}

DC3000 strains were used as pathogenic strains on tomato and Arabidopsis. DC3000 WT, the $\triangle$ oxyR mutant, and its complemented strains were grown at $28^{\circ} \mathrm{C}$ on $\mathrm{MG}$ medium containing $25 \mu \mathrm{g}$ of rifampicin per milliliter. Prior to inoculation, bacteria were suspended in sterile distilled $\mathrm{H}_{2} \mathrm{O}$ and bacterial cell optical densities at $600 \mathrm{~nm}\left(\mathrm{OD}_{600}\right)$ were measured using a JASCO V-730 spectrophotometer (JASCO, Tokyo).

\section{Generation of the $\Delta o x y R$ mutant and its complemented strains.}

The genetic region containing oxyR and its surrounding regions was amplified, using a set of PCR primers (66_1: $5^{\prime}$ GACCTGATGGACGTCATGAAC-3' and 66_2: 5'-CGCCA CTTGATAACCCGCTT- $3^{\prime}$ ) that were designed based on the registered sequence of DC3000 (NC_004578) with KOD FX DNA polymerase (Toyobo, Tokyo), then dAMP (deoxyadenosine monophosphate) was added to the $3^{\prime}$ end of the PCR product with $10 \times$ A-attachment mix (Toyobo). The resultant DNA was inserted into the pGEM-T Easy vector (Promega, Madison, WI, U.S.A.). 
Using a recombinant plasmid DNA, pGEM-oxyR, obtained as a template, inverse PCR was carried out using a set of primers (66_3: 5' -gctctagaAACGTGCGTCCATGAAGTTGCT-3' and 66_4: 5'-gctctagaCGAGCTAGGCAGTAGAGAGATG-3'; the lower-case letters show the artificial sequence for the digestion by $X b a \mathrm{I})$ to delete an ORF for oxyR. Then the PCR product and template DNA were digested with $X b a \mathrm{I}$ and DpnI. The resultant DNA was self-ligated with T4 DNA ligase (Ligation-convenience kit, Nippon Gene, Tokyo). The $o x y R$-deleted DNA construct was introduced into the EcoRI site of the mobilizable cloning vector pK18mobsacB (Schäfer et al. 1994). The resulting plasmid containing the DNA fragment lacking $o x y R$ was transformed into $E$. coli S17-1. The deletion mutant was obtained by conjugation and homologous recombination, according to the method previously reported (Shimizu et al. 2003). Transconjugants were selected on KB agar medium containing $30 \mu \mathrm{g}$ of kanamycin and $30 \mu \mathrm{g}$ of nalidixic acid per milliter. Because it was reported that an $\triangle$ oxyR mutant of Ralstonia solanacearum had a significantly reduced ability to form colonies on rich medium plates without catalase as compared with WT (Flores-Cruz and Allen 2011), we selected an $\Delta$ oxyR mutant strain on a KB agar plate containing $30 \mu \mathrm{g}$ of nalidixic acid per milliliter, $10 \%$ sucrose, and $0.1 \mathrm{mg}$ of catalase per milliliter. We confirmed that the application of catalase does not affect the growth of DC3000. The specific deletions of the $\Delta o x y R$ mutant were confirmed by PCR using primers 66_1 and 66_2.

To confirm whether the altered phenotype of the $\Delta o x y R$ mutant originates from a corresponding mutation, an $o x y R$ complemented strain was generated. The oxyR-containing DNA fragment from pGEM-oxyR was transferred into a transposon vector, pBSL118 (Alexeyev et al. 1995), at the EcoRI site, to generate pBSL-oxyR. The pBSL118-oxyR construct was introduced into the $\triangle o x y R$ mutant by conjugation, using an $E$. coli $\mathrm{S} 17-1 \lambda$ pir strain to generate the complemented strain $\Delta$ oxyR/oxyR. The DNA sequence of the mutated and complemented region was confirmed with DNA sequencing, using a BIG Dye terminator sequencing kit and DNA sequencer (ABI PRISM 3100; Applied Biosystems, Foster City, CA, U.S.A.).

\section{The growth curve assay.}

DC3000 strains, including WT, the $\triangle o x y R$ mutant, and complemented strain $\Delta o x y R / o x y R$ were grown at $28^{\circ} \mathrm{C}$ for $24 \mathrm{~h}$ in $\mathrm{KB}$ liquid medium. The strains were adjusted to an $\mathrm{OD}_{600}$ of 0.1 with fresh $\mathrm{KB}$ liquid medium, and the bacterial growth dynamics were investigated by measuring $\mathrm{OD}_{600}$ for $48 \mathrm{~h}$.

\section{Oxidative stress-tolerance assay.}

DC3000 strains including WT, the $\Delta$ oxyR mutant, and complemented strain $\Delta o x y R / o x y R$ were grown at $28^{\circ} \mathrm{C}$ for $24 \mathrm{~h}$ in $\mathrm{KB}$ liquid medium. The strains were adjusted to an $\mathrm{OD}_{600}$ of 0.5 with fresh $\mathrm{KB}$ medium, and $1 \mathrm{ml}$ of bacterial suspension was diluted in $15 \mathrm{ml}$ of $\mathrm{KB}$ medium with $0.3 \%$ agar. A paper disk $0.4 \mathrm{~cm}$ in diameter was placed in the center of the plate, and $10 \mu \mathrm{l}$ of $\mathrm{H}_{2} \mathrm{O}_{2}$ $(1,5$, or $10 \%)$ or menadione $(10$ or $50 \mathrm{mM})$ was applied to the disk. The plates were incubated at $28^{\circ} \mathrm{C}$ for $24 \mathrm{~h}$ and the diameters of the inhibition zones were measured.

\section{Seedling flood-inoculation method.}

A flood-inoculation method was used to observe disease symptoms in tomato and Arabidopsis as described previously (Ishiga et al. 2011; Uppalapati et al. 2009). Briefly, $40 \mathrm{ml}$ of bacterial suspension made in sterile distilled $\mathrm{H}_{2} \mathrm{O}$ containing 0.025\% Silwet L-77 (OSI Specialties Inc., Danbury, CT, U.S.A.) was dispensed into the plate containing 4-day-old tomato seedlings or 2-week-old Arabidopsis seedlings, to perform uniform inoculation, and the plates were incubated for 2 to $3 \mathrm{~min}$ at room temperature. After the bacterial suspension was removed by decantation, plates containing inoculated plants were sealed with $3 \mathrm{M}$ Micropore $2.5-\mathrm{cm}$ surgical tape $(3 \mathrm{M}$, St. Paul, MN, U.S.A.) and were incubated at $24^{\circ} \mathrm{C}$ with a light intensity of $200 \mu \mathrm{E} \mathrm{m}^{-2} \mathrm{~s}^{-1}$ and a 12-h-light and 12-h-dark photoperiod.

To determine bacterial growth in tomato and Arabidopsis leaves, we measured the internal bacterial population at several time points. For the determination of internal bacterial growth, inoculated plants were collected and the total weight of the inoculated plants was measured. After measurement of the weight, plants were surface-sterilized with $5 \% \mathrm{H}_{2} \mathrm{O}_{2}$ for 3 min. After washing three times with sterile distilled water, the plants were homogenized in sterile distilled water and the diluted samples were plated onto MG medium. Two days after plating of the diluted samples, the bacterial CFU were counted and normalized as CFU per milligram, using the total weights of the inoculated plants. The bacterial populations were evaluated in three independent experiments.

\section{Ion leakage measurements.}

Disease-associated cell death was estimated by measuring ion leakage from five plants treated with water (mock) or inoculated with DC3000 and incubated at $24^{\circ} \mathrm{C}$ with a light intensity of $200 \mu \mathrm{E} \mathrm{m} \mathrm{m}^{-2} \mathrm{~s}^{-1}$ and a 12-h-light and 12-h-dark photoperiod, as described previously (Ishiga et al. 2012; Uppalapati et al. 2009). The inoculated plants were collected and were gently agitated in $30 \mathrm{ml}$ of distilled water for $3 \mathrm{~h}$, and the leachates were measured, using an ion conductivity meter (Omron, Kyoto, Japan). The plants were then autoclaved for $20 \mathrm{~min}$ to kill the cells and release the total ions into the water. The values relative to the whole ion content after autoclaving were used to express the percent ion leakage.

\section{Real-time qRT-PCR.}

For expression profiles of DC3000 genes in response to $\mathrm{H}_{2} \mathrm{O}_{2}$, bacteria were grown in MG liquid medium for $24 \mathrm{~h}$ and were then adjusted to an $\mathrm{OD}_{600}$ of 0.2 with fresh $\mathrm{MG}$ liquid medium. $\mathrm{H}_{2} \mathrm{O}_{2}$ was added to a final concentration of $1 \mathrm{mM}$, 100 , and $10 \mu \mathrm{M}$. To investigate the expression profiles of DC3000 genes during infection, Arabidopsis wild-type Col-0 plants were flood-inoculated with DC3000 WT or $\triangle o x y R$ at $5 \times 10^{6} \mathrm{CFU} / \mathrm{ml}$ for 24,48 , and $72 \mathrm{~h}$, and then, total RNA including plant and bacterial RNA were purified from infected leaves. To confirm uniform infection, the bacterial populations were obtained by homogenizing the inoculated leaves at 0 and 2 days. Mixed plant-bacterial RNA populations were utilized for the expression profiles without bacterial RNA enrichment. Total RNA extraction and real-time qRT-PCR were done as described previously (Ishiga et al. 2013). Total RNA was extracted using RNAiso Plus (TaKaRa, Shiga, Japan), according to the manufacturer's protocol. Two micrograms of total RNA was treated with gDNA Eraser (TaKaRa) to eliminate genomic DNA, and the DNase-treated RNA was reversetranscribed using the PrimeScript RT reagent kit (TaKaRa). The cDNA (1:20) was then used for qRT-PCR, which was performed using the primers listed in Supplementary Table S1 with SYBR Premix Ex Taq II (TaKaRa) on a thermal cycler dice real time system (TaKaRa). The DC3000 oprI (outer membrane lipoprotein precursor), proC (pyrroline-5-carboxylate reductase), and rpoD (RNA polymerase sigma factor) were used as internal controls to normalize gene expression (Taguchi and Ichinose 2013; Wei et al. 2012). The average cycle threshold values calculated using the second derivative maximum method from triplicate samples were used to determine the fold expression relative to the controls. 


\section{ACKNOWLEDGMENTS}

We thank C. Baker for editing the manuscript. This work was supported, in part, by the Program to Disseminate Tenure Tracking System, MEXT, Japan.

\section{LITERATURE CITED}

Abramovitch, R. B., and Martin, G. B. 2004. Strategies used by bacterial pathogens to suppress plant defenses. Curr. Opin. Plant Biol. 7:356-364

Alexeyev, M. F., Shokolenko, I. N., and Croughan, T. P. 1995. New miniTn5 derivatives for insertion mutagenesis and genetic engineering in gram-negative bacteria. Can. J. Microbiol. 41:1053-1055.

Bindschedler, L. V., Dewdney, J., Blee, K. A., Stone, J. M., Asai, T., Plotnikov, J., Denoux, C., Hayes, T., Gerrish, C., Davies, D. R., Ausubel, F. M., and Bolwell, G. P. 2006. Peroxidase-dependent apoplastic oxidative burst in Arabidopsis required for pathogen resistance. Plant J. 47:851-863.

Brooks, D. M., Bender, C. L., and Kunkel, B. N. 2005. The Pseudomonas syringae phytotoxin coronatine promotes virulence by overcoming salicylic acid-dependent defences in Arabidopsis thaliana. Mol. Plant Pathol. 6:629-639.

Brynildsen, M. P., Winkler, J. A., Spina, C. S., MacDonald, I. C., and Collins, J. J. 2013. Potentiating antibacterial activity by predictably enhancing endogenous microbial ROS production. Nat. Biotechnol. 31:160-165.

Buell, C. R., Joardar, V., Lindeberg, M., Selengut, J., Paulsen, I. T., Gwinn, M. L., Dodson, R. J., Deboy, R. T., Durkin, A. S., Kolonay, J. F., Madupu, R., Daugherty, S., Brinkac, L., Beanan, M. J., Haft, D. H., Nelson, W. C. Davidsen, T., Zafar, N., Zhou, L., Liu, J., Yuan, Q., Khouri, H., Fedorova, N., Tran, B., Russell, D., Berry, K., Utterback, T., Van Aken, S. E., Feldblyum, T. V., D’Ascenzo, M., Deng, W. L., Ramos, A. R., Alfano, J. R., Cartinhour, S., Chatterjee, A. K., Delaney, T. P., Lazarowitz, S. G., Martin, G. B., Schneider, D. J., Tang, X., Bender, C. L., White, O., Fraser, C. M., and Collmer, A. 2003. The complete genome sequence of the Arabidopsis and tomato pathogen Pseudomonas syringae pv. tomato DC3000. Proc. Natl. Acad. Sci. U.S.A. 100:10181-10186.

Bulgakov, V. P., Gorpenchenko, T. Y., Veremeichik, G. N., Shkryl, Y. N., Tchernoded, G. K., Bulgakov, D. V., Aminin, D. L., and Zhuravlev, Y. N. 2012. The rolB gene suppresses reactive oxygen species in transformed plant cells through the sustained activation of antioxidant defense. Plant Physiol. 158:1371-1381.

Burbank, L., and Roper, M. C. 2014. OxyR and SoxR modulate the inducible oxidative stress response and are implicated during different stages of infection for the bacterial phytopathogen Pantoea stewartil subsp. stewartii. Mol. Plant-Microbe Interact. 27:479-490.

Chandra-Shekara, A. C., Gupte, M., Navarre, D., Raina, S., Raina, R., Klessig, D., and Kachroo, P. 2006. Light-dependent hypersensitive response and resistance signaling against Turnip crinkle virus in Arabidopsis. Plant J. 45:320-334.

Charoenlap, N., Buranajitpakorn, S., Duang-Nkern, J., Namchaiw, P. Vattanaviboon, P., and Mongkolsuk, S. 2011. Evaluation of the virulence of Xanthomonas campestris pv. campestris mutant strains lacking functional genes in the OxyR regulon. Curr. Microbiol. 63:232-237.

Charoenlap, N., Eiamphungporn, W., Chauvatcharin, N., Utamapongchai, S., Vattanaviboon, P., and Mongkolsuk, S. 2005. OxyR mediated compensatory expression between $a h p C$ and $k a t A$ and the significance of ahpC in protection from hydrogen peroxide in Xanthomonas campestris. FEMS (Fed. Eur. Microbiol. Soc.) Microbiol. Lett. 249:73-78.

Chisholm, S. T., Coaker, G., Day, B., and Staskawicz, B. J. 2006. Hostmicrobe interactions: Shaping the evolution of the plant immune response. Cell 124:803-814.

Choi, H. W., Kim, Y. J., Lee, S. C., Hong, J. K., and Hwang, B. K. 2007. Hydrogen peroxide generation by the pepper extracellular peroxidase $\mathrm{CaPO} 2$ activates local and systemic cell death and defense response to bacterial pathogens. Plant Physiol. 145:890-904.

Cui, H., Tsuda, K., and Parker, J. E. 2015. Effector-triggered immunity: From pathogen perception to robust defense. Annu. Rev. Plant Biol. 66:487-511.

Doke, N. 1983. Generation of superoxide anion by potato tuber protoplasts during the hypersensitive response to hyphal wall components of Phytophthora infestans and specific inhibition of the reaction by suppressors of hypersensitivity. Physiol. Plant Pathol. 23:359-367.

Feil, H., Feil, W. S., Chain, P., Larimer, F., DiBartolo, G., Copeland, A., Lykidis, A., Trong, S., Nolan, M., Goltsman, E., Thiel, J., Malfatti, S., Loper, J. E., Lapidus, A., Detter, J. C., Land, M., Richardson, P. M., Kyrpides, N. C., Ivanova, N., and Lindow, S. E. 2005. Comparison of the complete genome sequences of Pseudomonas syringae pv. syringae B728a and pv. tomato DC3000. Proc. Natl. Acad. Sci. U.S.A. 102:11064-11069.

Ferreira, A. O., Myers, C. R., Gordon, J. S., Martin, G. B., Vencato, M., Collmer, A., Wehling, M. D., Alfano, J. R., Moreno-Hagelsieb, G.,
Lamboy, W. F., DeClerck, G., Schneider, D. J., and Cartinhour, S. W. 2006. Whole-genome expression profiling defines the HrpL regulon of Pseudomonas syringae pv. tomato DC3000, allows de novo reconstruction of the Hrp cis clement, and identifies novel coregulated genes. Mol. Plant-Microbe Interact. 19:1167-1179.

Flores-Cruz, Z., and Allen, C. 2011. Necessity of OxyR for the hydrogen peroxide stress response and full virulence in Ralstonia solanacearum. Appl. Environ. Microbiol. 77:6426-6432.

Fouts, D. E., Abramovitch, R. B., Alfano, J. R., Baldo, A. M., Buell, C. R., Cartinhour, S., Chatterjee, A. K., D’Ascenzo, M., Gwinn, M. L., Lazarowitz, S. G., Lin, N. C., Martin, G. B., Rehm, A. H., Schneider, D. J., van Dijk, K., Tang, X., and Collmer, A. 2002. Genomewide identification of Pseudomonas syringae pv. tomato DC3000 promoters controlled by the HrpL alternative sigma factor. Proc. Natl. Acad. Sci. U.S.A. 99:2275-2280.

Gawroński, P., Górecka, M., Bederska, M., Rusaczonek, A., Ślesak, I., Kruk, J., and Karpiński, S. 2013. Isochorismate synthase 1 is required for thylakoid organization, optimal plastoquinone redox status, and state transitions in Arabidopsis thaliana. J. Exp. Bot. 64:3669-3679.

Gimenez-Ibanez, S., and Rathjen, J. P. 2010. The case for the defense: Plants versus Pseudomonas syringae. Microbes Infect. 12:428-437.

Grant, M., and Lamb, C. 2006. Systemic immunity. Curr. Opin. Plant Biol. 9:414-420.

Greenberg, J. T., and Yao, N. 2004. The role and regulation of programmed cell death in plant-pathogen interactions. Cell. Microbiol. 6:201-211.

Guo, M., Block, A., Bryan, C. D., Becker, D. F., and Alfano, J. R. 2012. Pseudomonas syringae catalases are collectively required for plant pathogenesis. J. Bacteriol. 194:5054-5064.

Heo, Y. J., Chung, I. Y., Cho, W. J., Lee, B. Y., Kim, J. H., Choi, K. H., Lee, J. W., Hassett, D. J., and Cho, Y. H. 2010. The major catalase gene (katA) of Pseudomonas aeruginosa PA14 is under both positive and negative control of the global transactivator OxyR in response to hydrogen peroxide. J. Bacteriol. 192:381-390.

Ishiga, Y., Ishiga, T., Uppalapati, S. R., and Mysore, K. S. 2011. Arabidopsis seedling flood-inoculation technique: A rapid and reliable assay for studying plant-bacterial interactions. Plant Methods 7:32.

Ishiga, Y., Ishiga, T., Uppalapati, S. R., and Mysore, K. S. 2013. Jasmonate ZIM-domain (JAZ) protein regulates host and nonhost pathogen-induced cell death in tomato and Nicotiana benthamiana. PLoS One 8:e75728.

Ishiga, Y., Ishiga, T., Wangdi, T., Mysore, K. S., and Uppalapati, S. R. 2012. NTRC and chloroplast-generated reactive oxygen species regulate Pseudomonas syringae pv. tomato disease development in tomato and Arabidopsis. Mol. Plant-Microbe Interact. 25:294-306.

Ishiga, Y., Uppalapati, S. R., Ishiga, T., Elavarthi, S., Martin, B., and Bender, C. L. 2009. The phytotoxin coronatine induces light-dependent reactive oxygen species in tomato seedlings. New Phytol. 181:147-160.

Ishikawa, T., Takahara, K., Hirabayashi, T., Matsumura, H., Fujisawa, S. Terauchi, R., Uchimiya, H., and Kawai-Yamada, M. 2010. Metabolome analysis of response to oxidative stress in rice suspension cells overexpressing cell death suppressor Bax inhibitor-1. Plant Cell Physiol. 51: 9-20.

Joardar, V., Lindeberg, M., Jackson, R. W., Selengut, J., Dodson, R., Brinkac, L. M., Daugherty, S. C., Deboy, R., Durkin, A. S., Giglio, M. G., Madupu, R., Nelson, W. C., Rosovitz, M. J., Sullivan, S., Crabtree, J., Creasy, T., Davidsen, T., Haft, D. H., Zafar, N., Zhou, L., Halpin, R., Holley, T., Khouri, H., Feldblyum, T., White, O., Fraser, C. M., Chatterjee, A. K., Cartinhour, S., Schneider, D. J., Mansfield, J., Collmer, A., and Buell, C. R. 2005. Whole-genome sequence analysis of Pseudomonas syringae pv. phaseolicola 1448A reveals divergence among pathovars in genes involved in virulence and transposition. J. Bacteriol. 187:6488-6498.

Johnson, J. R., Russo, T. A., Drawz, S. M., Clabots, C., Olson, R., Kuskowski, M. A., and Rosen, H. 2013. OxyR contributes to the virulence of a Clonal Group A Escherichia coli strain $(\mathrm{O} 17: \mathrm{K}+: \mathrm{H} 18)$ in animal models of urinary tract infection, subcutaneous infection, and systemic sepsis. Microb. Pathog. 64:1-5.

Kadota, Y., Sklenar, J., Derbyshire, P., Stransfeld, L., Asai, S., Ntoukakis, V., Jones, J. D., Shirasu, K., Menke, F., Jones, A., and Zipfel, C. 2014 Direct regulation of the NADPH oxidase RBOHD by the PRRassociated kinase BIK1 during plant immunity. Mol. Cell 54:43-55.

Katagiri, F., Thilmony, R., and He, S. Y. 2002. The Arabidopsis thalianapseudomonas syringae interaction. Arabidopsis Book 1:e0039.

Keith, R. C., Keith, L. M., Hernández-Guzmán, G., Uppalapati, S. R., and Bender, C. L. 2003. Alginate gene expression by Pseudomonas syringae pv. tomato DC3000 in host and non-host plants. Microbiology 149: 1127-1138.

Kim, J., and Park, W. 2014. Oxidative stress response in Pseudomonas putida. Appl. Microbiol. Biotechnol. 98:6933-6946. 
Kobayashi, K., and Tagawa, S. 2004. Activation of SoxR-dependent transcription in Pseudomonas aeruginosa. J. Biochem. 136:607-615.

Lam, H. N., Chakravarthy, S., Wei, H. L., BuiNguyen, H., Stodghill, P. V., Collmer, A., Swingle, B. M., and Cartinhour, S. W. 2014. Global analysis of the HrpL regulon in the plant pathogen Pseudomonas syringae pv. tomato DC3000 reveals new regulon members with diverse functions. PLoS One 9:e106115.

Lau, G. W., Britigan, B. E., and Hassett, D. J. 2005. Pseudomonas aeruginosa OxyR is required for full virulence in rodent and insect models of infection and for resistance to human neutrophils. Infect. Immun. 73:2550-2553.

Lindeberg, M., Cunnac, S., and Collmer, A. 2012. Pseudomonas syringae type III effector repertoires: Last words in endless arguments. Trends Microbiol. 20:199-208.

Loake, G. 2001. Plant cell death: Unmasking the gatekeepers. Curr. Biol. 11:R1028-R1031

Loor, G., Kondapalli, J., Schriewer, J. M., Chandel, N. S., Vanden Hoek, T. L., and Schumacker, P. T. 2010. Menadione triggers cell death through ROS-dependent mechanisms involving PARP activation without requiring apoptosis. Free Radic. Biol. Med. 49:1925-1936.

Love, A. J., Laval, V., Geri, C., Laird, J., Tomos, A. D., Hooks, M. A., and Milner, J. J. 2007. Components of Arabidopsis defense- and ethylenesignaling pathways regulate susceptibility to Cauliflower mosaic virus by restricting long-distance movement. Mol. Plant-Microbe Interact. 20:659-670.

Macho, A. P., and Zipfel, C. 2014. Plant PRRs and the activation of innate immune signaling. Mol. Cell 54:263-272.

Makandar, R., Nalam, V., Chaturvedi, R., Jeannotte, R., Sparks, A. A., and Shah, J. 2010. Involvement of salicylate and jasmonate signaling pathways in Arabidopsis interaction with Fusarium graminearum. Mol. Plant-Microbe Interact. 23:861-870.

Massoud, K., Barchietto, T., Le Rudulier, T., Pallandre, L., Didierlaurent, L., Garmier, M., Ambard-Bretteville, F., Seng, J. M., and Saindrenan, P. 2012. Dissecting phosphite-induced priming in Arabidopsis infected with Hyaloperonospora arabidopsidis. Plant Physiol. 159:286-298.

Miguel, E., Poza-Carrión, C., López-Solanilla, E., Aguilar, I., Llama-Palacios, A., García-Olmedo, F., and Rodríguez-Palenzuela, P. 2000. Evidence against a direct antimicrobial role of $\mathrm{H}_{2} \mathrm{O}_{2}$ in the infection of plants by Erwinia chrysanthemi. Mol. Plant-Microbe Interact. 13:421-429.

Nomura, H., Komori, T., Uemura, S., Kanda, Y., Shimotani, K., Nakai, K., Furuichi, T., Takebayashi, K., Sugimoto, T., Sano, S., Suwastika, I. N., Fukusaki, E., Yoshioka, H., Nakahira, Y., and Shiina, T. 2012. Chloroplast-mediated activation of plant immune signalling in Arabidopsis. Nat. Commun. 3:926.

Nomura, K., Melotto, M., and He, S. Y. 2005. Suppression of host defense in compatible plant-Pseudomonas syringae interactions. Curr. Opin. Plant Biol. 8:361-368.

Osman, S. F., Fett, W. F., and Fishman, M. L. 1986. Exopolysaccharides of the phytopathogen Pseudomonas syringae pv. glycinea. J. Bacteriol. 166:66-71.

Panmanee, W., and Hassett, D. J. 2009. Differential roles of OxyRcontrolled antioxidant enzymes alkyl hydroperoxide reductase (AhpCF) and catalase (KatB) in the protection of Pseudomonas aeruginosa against hydrogen peroxide in biofilm vs. planktonic culture. FEMS (Fed. Eur. Microbiol. Soc.) Microbiol. Lett. 295:238-244.

Pieterse, C. M., Van der Does, D., Zamioudis, C., Leon-Reyes, A., and Van Wees, S. C. 2012. Hormonal modulation of plant immunity. Annu. Rev. Cell Dev. Biol. 28:489-521.

Pomposiello, P. J., and Demple, B. 2001. Redox-operated genetic switches: The SoxR and OxyR transcription factors. Trends Biotechnol. 19:109-114.

Pomposiello, P. J., and Demple, B. 2002. Global adjustment of microbial physiology during free radical stress. Adv. Microb. Physiol. 46:319-341.

Rietz, S., Stamm, A., Malonek, S., Wagner, S., Becker, D., MedinaEscobar, N., Vlot, A. C., Feys, B. J., Niefind, K., and Parker, J. E. 2011. Different roles of enhanced disease susceptibility1 (EDS1) bound to and dissociated from phytoalexin deficient4 (PAD4) in Arabidopsis immunity. New Phytol. 191:107-119.

Robert-Seilaniantz, A., Grant, M., and Jones, J. D. 2011. Hormone crosstalk in plant disease and defense: More than just jasmonate-salicylate antagonism. Annu. Rev. Phytopathol. 49:317-343.

Rojas, C. M., Senthil-Kumar, M., Wang, K., Ryu, C. M., Kaundal, A., and Mysore, K. S. 2012. Glycolate oxidase modulates reactive oxygen species-mediated signal transduction during nonhost resistance in Nicotiana benthamiana and Arabidopsis. Plant Cell 24:336-352.

Schäfer, A., Tauch, A., Jäger, W., Kalinowski, J., Thierbach, G., and Pühler, A. 1994. Small mobilizable multi-purpose cloning vectors derived from the
Escherichia coli plasmids pK18 and pK19: Selection of defined deletions in the chromosome of Corynebacterium glutamicum. Gene 145:69-73.

Seth, D., Hausladen, A., Wang, Y. J., and Stamler, J. S. 2012. Endogenous protein S-nitrosylation in E. coli: regulation by OxyR. Science 336:470-473.

Shimizu, R., Taguchi, F., Marutani, M., Mukaihara, T., Inagaki, Y., Toyoda, K., Shiraishi, T., and Ichinose, Y. 2003. The DeltafliD mutant of Pseudomonas syringae pv. tabaci, which secretes flagellin monomers, induces a strong hypersensitive reaction (HR) in non-host tomato cells. Mol. Genet. Genomics 269:21-30.

Sreedharan, A., Penaloza-Vazquez, A., Kunkel, B. N., and Bender, C. L. 2006. CorR regulates multiple components of virulence in Pseudomonas syringae pv. tomato DC3000. Mol. Plant-Microbe Interact. 19:768-779.

Taguchi, F., and Ichinose, Y. 2013. Virulence factor regulator (Vfr) controls virulence-associated phenotypes in Pseudomonas syringae pv. tabaci 6605 by a quorum sensing-independent mechanism. Mol. Plant Pathol. 14:279-292.

Toledo, M. A., Schneider, D. R., Azzoni, A. R., Favaro, M. T., Pelloso, A. C. Santos, C. A., Saraiva, A. M., and Souza, A. P. 2011. Characterization of an oxidative stress response regulator, homologous to Escherichia coli OxyR, from the phytopathogen Xylella fastidiosa. Protein Expr. Purif. 75:204-210.

Torres, M. A. 2010. ROS in biotic interactions. Physiol. Plant. 138:414-429.

Torres, M. A., Dangl, J. L., and Jones, J. D. 2002. Arabidopsis gp91phox homologues AtrbohD and AtrbohF are required for accumulation of reactive oxygen intermediates in the plant defense response. Proc. Natl. Acad. Sci. U.S.A. 99:517-522.

Uppalapati, S. R., Ishiga, Y., Wangdi, T., Kunkel, B. N., Anand, A., Mysore, K. S., and Bender, C. L. 2007. The phytotoxin coronatine contributes to pathogen fitness and is required for suppression of salicylic acid accumulation in tomato inoculated with Pseudomonas syringae pv. tomato DC3000. Mol. Plant-Microbe Interact. 20:955-965.

Uppalapati, S. R., Ishiga, Y., Wangdi, T., Urbanczyk-Wochniak, E., Ishiga, T., Mysore, K. S., and Bender, C. L. 2008. Pathogenicity of Pseudomonas syringae pv. tomato on tomato seedlings: Phenotypic and gene expression analyses of the virulence function of coronatine. Mol. Plant-Microbe Interact. 21:383-395.

Uppalapati, S. R., Marek, S. M., Lee, H. K., Nakashima, J., Tang, Y., Sledge, M. K., Dixon, R. A., and Mysore, K. S. 2009. Global gene expression profiling during Medicago truncatula-Phymatotrichopsis omnivora interaction reveals a role for jasmonic acid, ethylene, and the flavonoid pathway in disease development. Mol. Plant-Microbe Interact. 22:7-17.

Van Breusegem, F., and Dat, J. F. 2006. Reactive oxygen species in plant cell death. Plant Physiol. 141:384-390.

Wei, Q., Minh, P. N., Dötsch, A., Hildebrand, F., Panmanee, W., Elfarash, A., Schulz, S., Plaisance, S., Charlier, D., Hassett, D., Häussler, S., and Cornelis, P. 2012. Global regulation of gene expression by OxyR in an important human opportunistic pathogen. Nucleic Acids Res. 40:4320-4333.

Wiermer, M., Feys, B. J., and Parker, J. E. 2005. Plant immunity: The EDS1 regulatory node. Curr. Opin. Plant Biol. 8:383-389.

Xin, X. F., and He, S. Y. 2013. Pseudomonas syringae pv. tomato DC3000: A model pathogen for probing disease susceptibility and hormone signaling in plants. Annu. Rev. Phytopathol. 51:473-498.

Yeom, S., Yeom, J., and Park, W. 2010. Molecular characterization of FinR, a novel redox-sensing transcriptional regulator in Pseudomonas putida KT2440. Microbiology 156:1487-1496.

Yi, S. Y., Shirasu, K., Moon, J. S., Lee, S. G., and Kwon, S. Y. 2014. The activated SA and JA signaling pathways have an influence on flg22triggered oxidative burst and callose deposition. PLoS One. 9:e88951.

Yoshioka, H., Numata, N., Nakajima, K., Katou, S., Kawakita, K., Rowland, O., Jones, J. D., and Doke, N. 2003. Nicotiana benthamiana gp91phox homologs NbrbohA and NbrbohB participate in $\mathrm{H}_{2} \mathrm{O}_{2}$ accumulation and resistance to Phytophthora infestans. Plant Cell 15:706-718.

Yu, J., Peñaloza-Vázquez, A., Chakrabarty, A. M., and Bender, C. L. 1999. Involvement of the exopolysaccharide alginate in the virulence and epiphytic fitness of Pseudomonas syringae pv. syringae. Mol. Microbiol. 33:712-720.

Zhang, J., and Zhou, J. M. 2010. Plant immunity triggered by microbial molecular signatures. Mol. Plant 3:783-793.

Zheng, M., Aslund, F., and Storz, G. 1998. Activation of the OxyR transcription factor by reversible disulfide bond formation. Science 279: 1718-1722.

Zipfel, C. 2008. Pattern-recognition receptors in plant innate immunity. Curr. Opin. Immunol. 20:10-16. 